\title{
OSADNICTWO NA WYSPIE THIRA (SANTORYN) OD NEOLITU PO PÓŹNĄ EPOKĘ BRĄZU
}

\author{
THE OCCUPATION OF THERA ISLAND (SANTORINI) \\ FROM THE NEOLITHIC UNTIL THE LATE BRONZE AGE
}

\author{
Mariusz Kufel \\ Instytut Prahistorii, Uniwersytet im. Adama Mickiewicza \\ ul. Św. Marcin 78, 61-809 Poznań, Poland
}

\begin{abstract}
This article presents a history of the Thera Island occupation in the Neolithic and Bronze Age. Altogether, 13 settlements and 2 cemeteries have been recorded from this period. The island was inhabited until the Late Bronze Age. The most significant centre on the island was surely the town of Akrotiri. At the beginning of the Late Bronze Age, a large eruption of the Santorini volcano took place which ceased the occupation and covered the almost entire island with a thick layer of pumice.
\end{abstract}

Kompleks Thira (Santoryn) $\left(36,40^{\circ} \mathrm{N}, 25,40^{\circ} \mathrm{E}\right)$ (ryc. 1) w obecnej postaci składa się z wysp: Thira $\left(75,8 \mathrm{~km}^{2}\right)$, Thirassia $\left(9,3 \mathrm{~km}^{2}\right)$, Aspronisi $\left(0,1 \mathrm{~km}^{2}\right)$, Palea Kameni $\left(0,5 \mathrm{~km}^{2}\right)$ i Nea Kameni $\left(3,4 \mathrm{~km}^{2}\right)$. Położony on jest w południowej części Morza Egejskiego, około $100 \mathrm{~km}$ na północ od wyspy Krety. Obszar ten jest nacechowany silnymi przejawami wulkanizmu. W jego bogatej historii geologicznej wyróżnia się około dwudziestu wielkich erupcji wulkanicznych. Ostatni największy przejaw działalności plutonicznej na Thirze miał miejsce w późnej epoce brązu (XVII w. p.n.e.). Jego wynikiem było zasypanie materiałem, uwolnionym podczas erupcji, największego centrum osadniczego na wyspie (miasta Akrotiri), które powszechnie zwie się drugimi „Pompejami”, będącymi nieocenionym źródłem do rekonstrukcji życia i organizacji społecznej nie tylko tego obszaru, ale także całego Śródziemnomorza.

\section{WYSPA THIRA W OKRESIE NEOLITU (4700/4500-3300-3100 p.n.e.) (tab. 1)}

Przez długi czas panowała opinia, że wyspa Thira była niezasiedlona w okresie neo${ }_{\text {litu }}{ }^{1}$. Powszechnie uważano także, że nie miała ona żadnego znaczenia $w$ handlu w inte-

\footnotetext{
${ }^{1}$ Cherry 1981 , s. 55.
} 


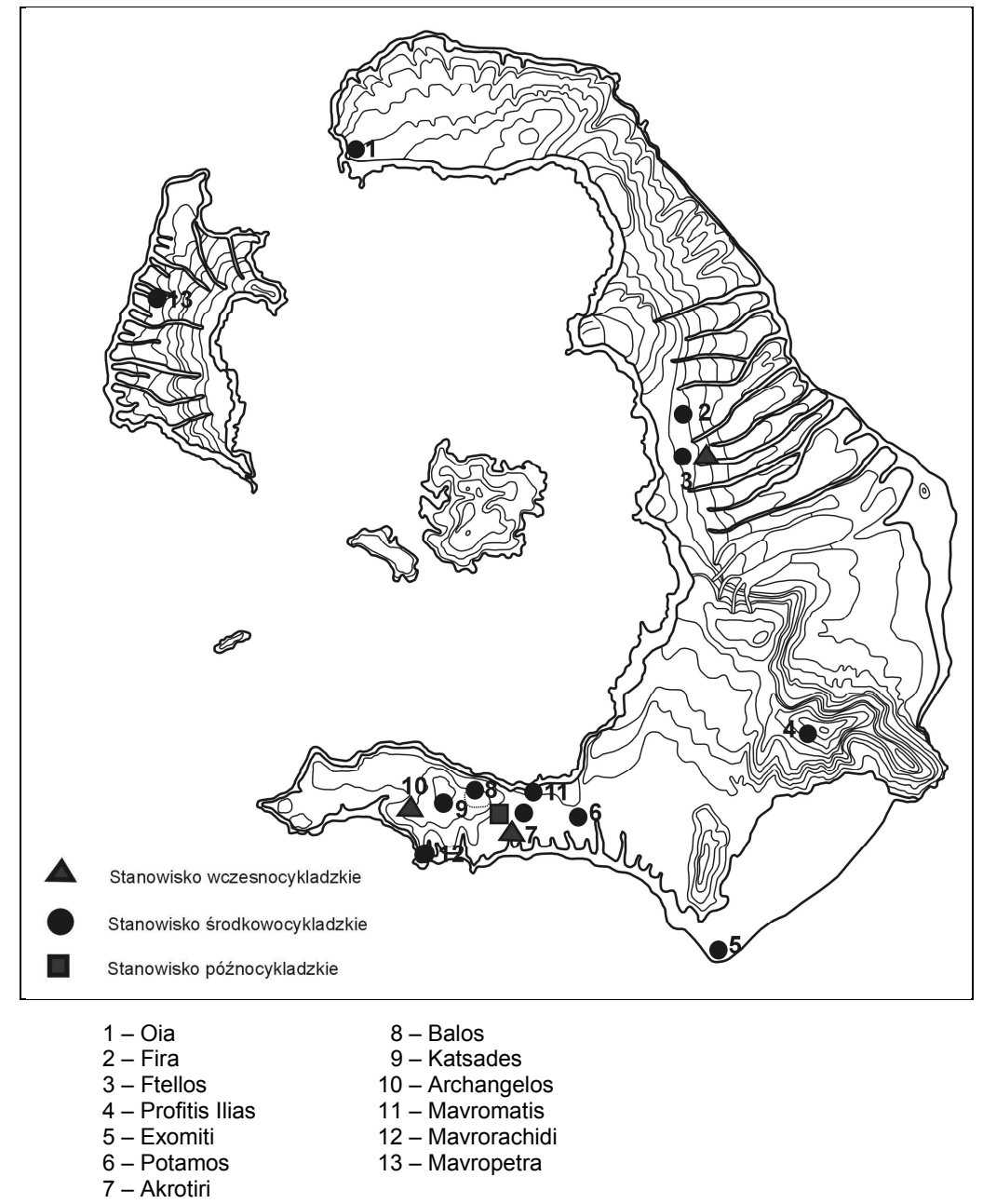

Ryc. 1. Kompleks Santoryn z zaznaczeniem osadnictwa (wg Marin a tos 1967, z modyfikacjami autora artykułu)

Fig. 1. The Santorini complex (Marinatos 1967 with modifications)

resującym nas okresie ${ }^{2}$. Wieloletnie prace wykopaliskowe prowadzone na stanowisku Akrotiri dostarczyły jednakże danych potwierdzających bardzo wczesne osadnictwo w okresie neolitycznym na tej wyspie. Grecka archeolog P. Sotirakopoulou z uniwersytetu w Atenach, badając ceramikę pozyskaną podczas wykopalisk na stanowisku Akrotiri, wydzieliła kilkadziesiąt fragmentów ceramicznych, które na podstawie motywu zdobniczego zaklasyfikowała do ceramiki neolitycznej, charakterystycznej dla tego okresu w strefie cykladzkiej.

${ }^{2}$ Van Andel, Runnels 1988, s. 237. 
Tabela 1. Chronologia bezwzględna kultur egejskich wg Warren, Hankey 1989 (wg Lewartowski, Ulanowska 1998, z modyfikacjami autora)

Table 1. Table of a relative chronology of the Aegean cultures according to Warren, Hankey 1989 (Lewartowski, Ulanowska 1998 with modifications)

\begin{tabular}{|c|c|c|}
\hline KRETA & CYKLADY & LĄD GRECKI \\
\hline $4800-3800$ & PN $5400 / 5300-4700 / 4500$ & PN $5400 / 5300-4700 / 4500$ \\
\hline $3800-3500$ & SN $4700 / 4500-3300 / 3100$ & SN $4700 / 4500-3300 / 3100$ \\
\hline Okres wczesnominojski & Okres wczesnocykladzki & Okres wczesnohelladzki \\
\hline $3650 / 3500-3000 / 2900$ & WC I $\quad 3500-2900$ & $3600-2900 \pm$ \\
\hline & Kampos $2900 / 2800$ & \\
\hline WM II $\quad 2900-2300 / 2150$ & WC II $\quad 2800 / 2700-2400 / 2300$ & $2900 \pm-2570 / 2410$ \\
\hline WM III $\quad 2300 / 2150-2160 / 2025$ & WC III $\quad 2400 / 2300-2050 / 1950$ & WH III $\quad 2570 / 2410-2090 / 2050$ \\
\hline Okres średniomminojski & Okres średniocykladzki & Okres średniohelladzki \\
\hline ŚM IA $\quad 2160 / 1979-X X$ w. & 2050/1950 i później & 2090/2050 i później \\
\hline ŚM IB XIX w. & & \\
\hline ŚM II $\quad$ XIX w.-1700/1650 & & \\
\hline ŚM IIIA $1700 / 1650-1640 / 1630$ & & \\
\hline ŚM IIIB 1640/1630-1600 & & \\
\hline ŚM IIIB/PM IA granica 1600 & & \\
\hline Okres późnominojski & Okres późnocykladzki & Okres późnohelladzki \\
\hline PM IA $\quad 1600 / 1580-1480 \pm$ & od $1600 \pm$ & $1600-1510 / 1500$ \\
\hline $1480 \pm-1425$ & & PH IIA $\quad 1510 / 1500-1440$ \\
\hline $1425-1390$ & & PH IIB $\quad 1440-1390 \pm$ \\
\hline PM IIIA1 $1390-1370 / 1360$ & & PH IIIA1 $1390 \pm 1370 / 1360$ \\
\hline PM IIIA2 $1370 / 1360-1340 / 1330$ & & PH IIIA2 $1370 / 1360-1340 / 1330$ \\
\hline PM IIIB $\quad 1340 / 1330-1190 \pm$ & & $1340 / 1330-1185 / 1180$ \\
\hline PM IIIC $\quad 1190 \pm-1170 \pm$ & & $1185 / 1180-1165$ \\
\hline
\end{tabular}

PN - okres późnego neolitu

$\mathrm{SN}$ - okres schyłkowego neolitu

WM/WC/WH okres wczesnominojski/ wczesnocykladzki/ wczesnohelladzki

ŚM/ŚC/ŚH okres środkowominojski/ środkowocykladzki/środkowohelladzki

$\mathrm{PM} / \mathrm{PC} / \mathrm{PH}$ okres późnominojski/późnocykladzki/późnohelladzki

Do tego inwentarza należy dodać fragment grotu strzały z obsydianu, w kształcie liścia, który ma swoje analogie w neolitycznej kulturze cykladzkiej. Na tej podstawie zakłada się, że już od bardzo wczesnych czasów istniała mała, położona na wybrzeżu osada, która nie tylko utrzymywała kontakty z ośrodkami znanymi z tego samego okresu z innych wysp Archipelagu Cykladzkiego (Saliagos na Antiparos, Grotta na Naksos, Mavri Spelia i Ftelia na Mikonos oraz osada neolityczna na wyspie Amorgos), ale również z osadnictwem występującym w tym czasie na Dodekanezie (np. Archangelos na Rodos) $)^{3}$.

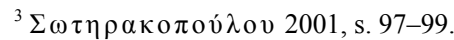



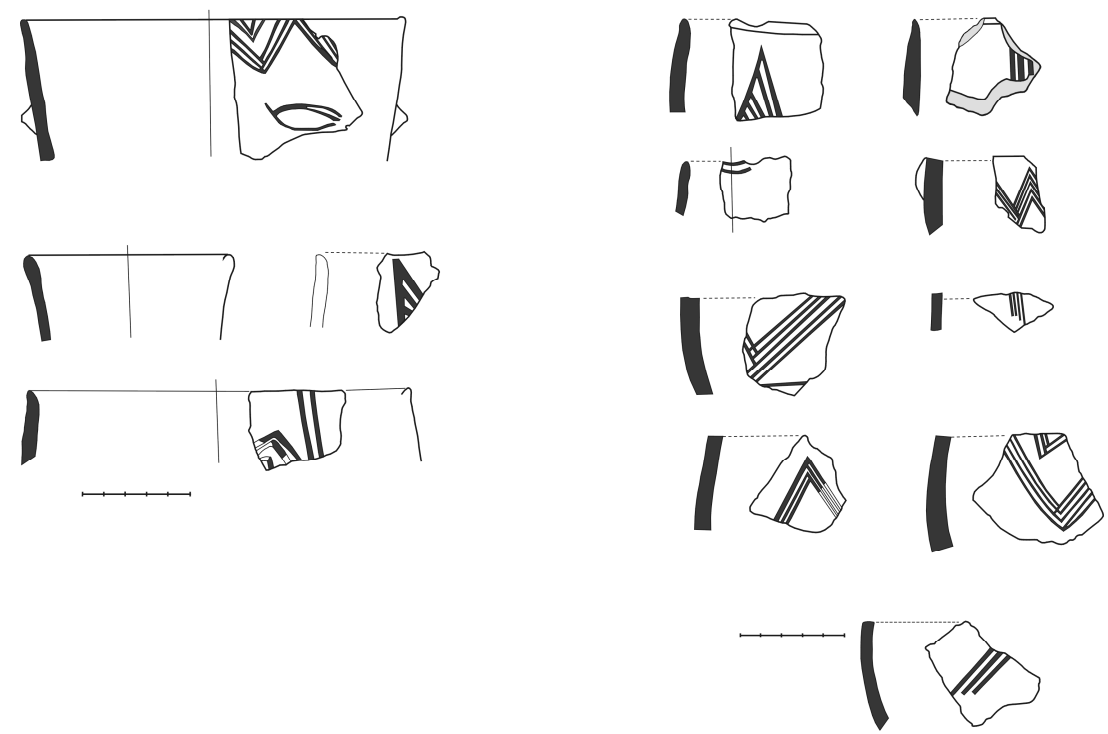

Ryc. 2. Akrotiri. Wybór ceramiki neolitycznej (wg $\Sigma \omega \tau \eta \rho \alpha \kappa o \pi \circ v ́ \lambda o v 2001)$

Fig. 2. Akrotiri. A selection of the Neolithic pottery ( $\Sigma \omega \tau \eta \rho \alpha \kappa \circ \pi \circ v$ $\lambda$ ov 2001)

Wymieniony zbiór pochodzi z obszaru Xeste 3 lub jego bezpośredniego sąsiedztwa, tzn. położonego najbardziej na południowy zachód fragmentu osiedla Akrotiri (ryc. 2). Można sądzić, że obszar obecnego Xeste 3 stanowił rdzeń osady z późnego neolitu i mógł on także być centralną częścią w okresie następnym, a więc wczesnocykladzkim ${ }^{4}$. C. Doumas zaproponował koncepcję, że na półwyspie Akrotiri musiała istnieć niewielka neolityczna osada, z której na przestrzeni wieków powstało starożytne miasto ${ }^{5}$. Proces rozrastania się osady następował w kierunku wschodnim i północno-wschodnim ${ }^{6}$.

Stanowisko Xeste 3 położone jest na niewielkim wzgórzu sięgającym około 20-25 m n.p.m. ${ }^{7}$ Stok wzniesienia łagodnie opada w kierunku morza, dostarczając tym samym dobrego do niego dostępu. To wzgórze zbudowane jest głównie ze skał pochodzenia wulkanicznego. Obiekt ten był bardzo dobrze zlokalizowany z punktu widzenia żeglugi (położenie w niewielkiej zatoczce, otaczające wzgórza, chroniące przed silnymi wiatrami z północy). To zapewne stanowiło zasadniczy czynnik dla założenia w pobliżu osady niewielkiego portu. Obecnie panuje jednoznaczna opinia, że port w późnej epoce brązu znajdował się pomiędzy wzgórzami Mesavouno a Mavrorachidi (ryc. 1, 3). Nie ma jednak pewności, czy to założenie istniało już w późnym neolicie ${ }^{8}$.

\footnotetext{
${ }^{4}$ Sotirakopoulou 1990, s. 47.

${ }^{5}$ Doumas 1990, s. 48.

${ }^{6}$ Sotirakopoulou 1990, s. 47.

${ }^{7}$ Palyvou 1986, s. 179-181.

${ }^{8}$ Doumas 1983, s. 55, 56.
} 


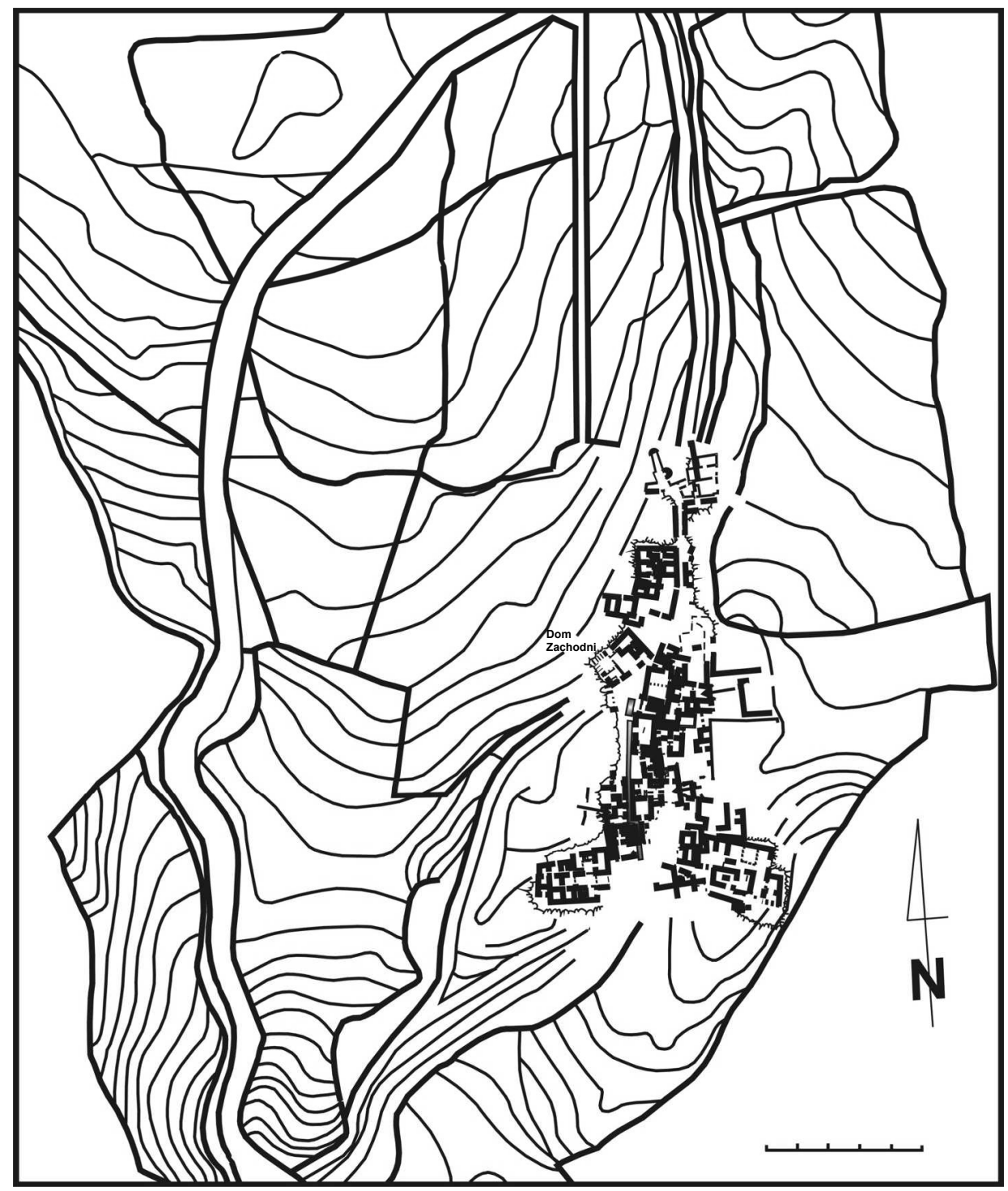

Ryc. 3. Plan warstwicowy stanowiska Akrotiri (wg П $\alpha \lambda v \beta$ ov́ 1999)

Fig. 3. A contour plan of the Akrotiri site ( $\alpha \lambda \nu \beta \beta$ ov 1999)

Innym czynnikiem preferującym taką lokalizację portu był układ wiatrów. Otóż od tej strony wyspy wiatry są najsłabsze i najbardziej przychylne dla żeglugi. Ponadto miejsce to oferuje dobre kotwicowisko dla statków. Nie ulega przy tym wątpliwości, że domniemany port neolityczny, istniejący w miejscu postulowanym przez archeologów, 
byłby ponadto elementem potwierdzającym ekonomiczne znaczenie morza dla mieszkańców wyspy (połowy, wymiana). Niektórzy badacze uważają, że właśnie neolityczna wymiana prowadzona drogą morską musiała odgrywać najważniejszą rolę przy wyborze miejsca na osadę i na przyszły port ${ }^{9}$. Położenie wyspy z punktu widzenia sieci komunikacyjnej pozwala uznać ją jako ważne ogniwo w całej strefie egejskiej ${ }^{10}$.

Przedmioty z obsydianu znajdowane na wyspie sugerują jej ścisłe uczestnictwo w wymianie z ludnością wyspy Milos, która w tym czasie była głównym dostarczycielem tego surowca, niezbędnego do produkcji narzędzi. Wiadomo z innych źródeł, że obsydian melijski docierał nawet na wyspę Kretę ${ }^{11}$. Nie można zatem zanegować roli wyspy Thiry jako potencjalnego uczestnika w tej wymianie, a być może nawet czynnego pośrednika pomiędzy Kretą i wyspą Milos, a prawdopodobnie także innymi regionami Morza Egejskiego ${ }^{12}$.

Pozostaje do rozstrzygnięcia kwestia, jaka rola przypadła wyspie w tym procesie. Czy była ona tylko biernym odbiorcą lub pośrednikiem? Wiele dowodów wskazuje na to, że tak nie było. Bardzo cennym dobrem handlowym, używanym nie tylko na obszarze egejskim, ale także w Egipcie i innych regionach śródziemnomorza był pumeks. Dotychczas zlokalizowano tylko trzy miejsca występowania tego surowca. Powszechnie wiadomo, że jest to minerał uwalniany w trakcie erupcji wulkanicznych, zatem centrami, które mogą go dostarczać na obszarze egejskim są trzy wyspy wulkaniczne: Thira, Nisiros oraz Milos. Pumeks odgrywał bardzo ważną rolę w gospodarce, służył jako materiał ścierny, szlifierski, składnik do czyszczenia skóry i zębów, środek do depilacji oraz pigment do farb ${ }^{13}$. Pumeks zarejestrowano w warstwach neolitycznych z Knossos oraz w innych ośrodkach na Krecie, a także w Saliagos na Antiparos ${ }^{14}$. $Z$ tego powodu jednoznaczna ocena, czy materiał ów docierał na Kretę drogą wymiany, czy też poprzez dyspersję poerupcyjną, jest znacznie utrudniona. Wszystkie zebrane dane wskazują na potencjalnie znaczącą rolę omawianego stanowiska w neolitycznej wymianie.

Bardzo ważną cechą środowiskową, z punktu widzenia osadnictwa regionu, jakim jest półwysep Akrotiri, są gleby. Omawiany obszar podlegał najwcześniejszym przekształceniom wulkanicznym, jakie wystąpiły na wyspie, co doprowadziło w konsekwencji do wykształcenia się bardzo urodzajnych gleb, bogatych we wszelkiego rodzaju składniki mineralne, które stymulowały aktywność rolniczą w tym regionie ${ }^{15}$.

Podsumowując, zakłada się, że mieszkańcy tej niewielkiej neolitycznej osady na półwyspie Akrotiri mogli zajmować się rolnictwem, ze względu na dobrą jakość ży-

\footnotetext{
${ }^{9}$ Doumas 1983, s. 11.

${ }^{10}$ Van Ande1, Runnels 1988, s. 236.

${ }^{11}$ Faure 1971, s. 422-423.

${ }^{12}$ Renfrew 1971, s. 430-436; Moundrea-Agrafioti 1990, s. 391.

${ }^{13}$ Faure 1971, s. 422-427.

${ }^{14}$ Renfrew 1971, s. 434.

${ }^{15}$ Davidson 1979 , s. $725-739$.
} 
znych gleb. Położenie blisko morza oraz łatwy do niego dostęp dawały możliwości budowy założeń portowych, a co za tym idzie perspektywę uprawiania dalekosiężnego handlu (wymiany) oraz wykorzystania żywnościowych zasobów morza ${ }^{16}$.

\section{WYSPA THIRA WE WCZESNEJ EPOCE BRĄZU (WEB) (ryc. 1)}

Kolejna faza zasiedlenia wyspy przypadała na wczesną epokę brązu lub w przypadku Cyklad - na okres wczesnocykladzki. Okres ten dzieli się na trzy podokresy, zgodnie z chronologią cykladzką: wczesnocykladzki I, II oraz III.

\subsection{Okres wczesnocykladzki I (WC I) (3500-2900 p.n.e.)}

Przełom epoki neolitu i wczesnej epoki brązu był nacechowany kontynuacją kulturową i wyspa Thira podlegała $\mathrm{w}$ dużej mierze wzorcom przemian zachodzących $\mathrm{w}$ tym czasie na Cykladach. Z tego okresu znana jest tylko osada Akrotiri, która znacznie się rozrasta, oraz prawdopodobnie cmentarzysko, znajdujące się w okolicach dzisiejszego miasta Fira. Być może niedaleko znajdowała się związana z nim osada, ale jej śladów jak dotychczas nie odnaleziono ${ }^{17}$. W przypadku Akrotiri można jednoznacznie stwierdzić istnienie osady z tego okresu, w przypadku cmentarzyska Fira nie ma jednak takiej pewności. Stanowisko to położone jest na południe od Fira i zostało odkryte podczas wydobywania pumeksu w $1930 \mathrm{r}$. Materiał ceramiczny pochodzący stąd nie pozwala jednoznacznie stwierdzić, czy nekropolia pochodzi z omawianego okresu. Za to nie ulega wątpliwości, że istniała w drugim okresie, a mianowicie wczesnocykladzkim II.
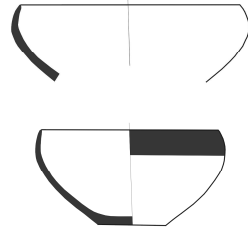

A)
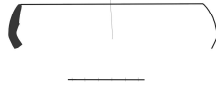

B)

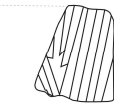

C)

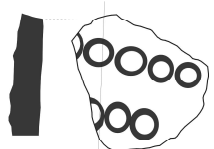

Ryc. 4. Akrotiri. Ceramika z okresu wczesnocykladzkiego I (wg $\Sigma \omega \tau \eta \rho \alpha \kappa o \pi$ o v́ $\lambda$ ov 2001)

Fig. 4. Akrotiri. A selection of the EC I ceramic forms ( $\Sigma \omega \tau \eta \rho \alpha \kappa o \pi \circ v i \lambda o v 2001)$

\footnotetext{
${ }^{16}$ Forsyth 1997, s. 16.

${ }^{17}$ Doumas 1983, s. 27.
} 
Z WC I pochodzi jeden idol, który znajduje się obecnie w muzeum firańskim. W przypadku Akrotiri sytuacja wygląda wyraźniej, ponieważ z WC I identyfikuje się kilka fragmentów ceramicznych (ryc. 4) oraz kilka idoli.

\subsection{Okres wczesnocykladzki II (WC II) (2800/2700-2400/2300 p.n.e)}

Z okresem wczesnocykladzkim II związane są osady z (a) Akrotiri, (b) Archangelos, (c) Wysp Christiana oraz cmentarzysko (d) położone niedaleko miejscowości Fira. Ponadto materiały związane z tym okresem znane są z okolic (e) Megalochori oraz (f) Fira.

(a) W okresie WC II dużą rolę zaczęła odgrywać z całą pewnością osada w Akrotiri. Zarejestrowano tam bardzo wiele fragmentów ceramicznych naczyń o różnych kształtach, identyfikowanych z okresem WC II $^{18}$, a ponadto należy dodać jeszcze figurkę idola typu ,ze zgiętymi rękami”, odkrytą w pomieszczeniu 5 Kompleksu Beta w 1971 r. oraz 3 niewielkie figurki z Xeste 3, które zostały znalezione podczas wykopalisk w 1992 r. Niedaleko Kompleksu Delta odkryto marmurowe naczynia datowane na okres WC II (ryc. 5, 6) ${ }^{19}$. W tej jednostce czasu plasuje się także 9 figurek, które zostały znalezione również w Akrotiri, jednak w kontekście późnobrązowym. Badacze zakładają, że dostały się one do niego w trakcie prac restauracyjnych, przeprowadzonych przez mieszkańców miasta po trzęsieniu ziemi w późnej epoce brązu. Podczas odbudowy swoich domostw natknęli oni się na figurki, które starannie zebrali, a następnie zdeponowali w jednym miejscu $^{20}$.

(b) $\mathrm{W}$ interesującym nas okresie istniała zapewne niewielka osada położona na wzgórzu Archangelos, które uniknęło silnej akumulacji tefry, wyemitowanej w trakcie wybuchu minojskiego. W 1978 r. przeprowadzono na nim badania powierzchniowe. Materiał, który pozyskano, stanowią fragmenty ceramiczne pochodzące z okresu WC II oraz $\mathrm{PC}^{21}$.

Z okresem WC II wiąże się także fragmenty dużych naczyń zasobowych, których ucha są zdobione ornamentem promienistym, charakterystycznym dla tego przedziału czasu $^{22}$.

(c) Poza wyspą Thira ślady działalności ludzkiej w WC II stwierdzono także na Wyspach Christiana, odległych około 14 mil morskich na południowy zachód od Thiry. Na największej z wysp w 1966 r. odkryto ziemiankę, której ściany zostały umocnione konstrukcją kamienną. Zbliżona była formą do innych tego typu założeń identyfikowanych z badanym okresem. Analogie do niej odkryto np. w miejscowości Ftellos. Podczas eksploracji ziemianki pozyskano wiele naczyń ceramicznych oraz ich fragmentów, dato-

\footnotetext{
${ }^{18}$ Sotirakopoulou 1990, s. 43.

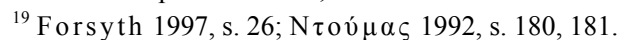

${ }^{20}$ Marinatos 1972, s. 23.

${ }^{21}$ Doumas 1983, s. 27.

${ }^{22} \Sigma \omega \tau \eta \rho \alpha \kappa о \pi$ о $\lambda$ ov 2001, s. 99-100.
} 
A)
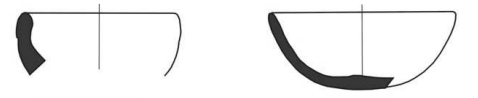

B)
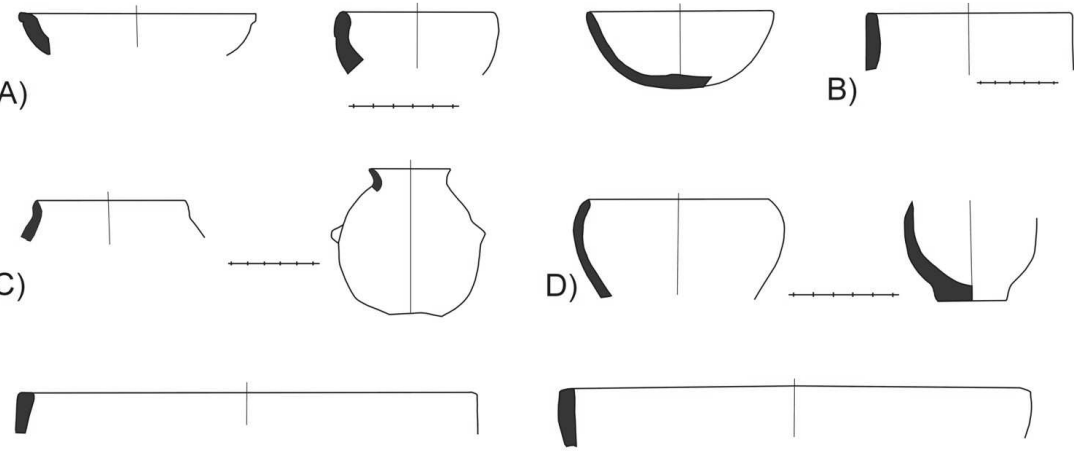

E)

F)
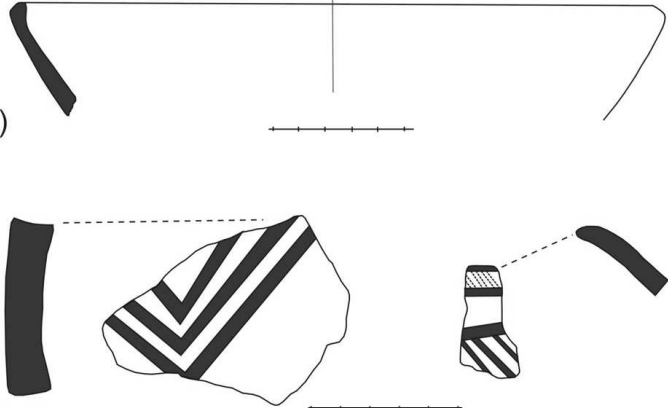

H)
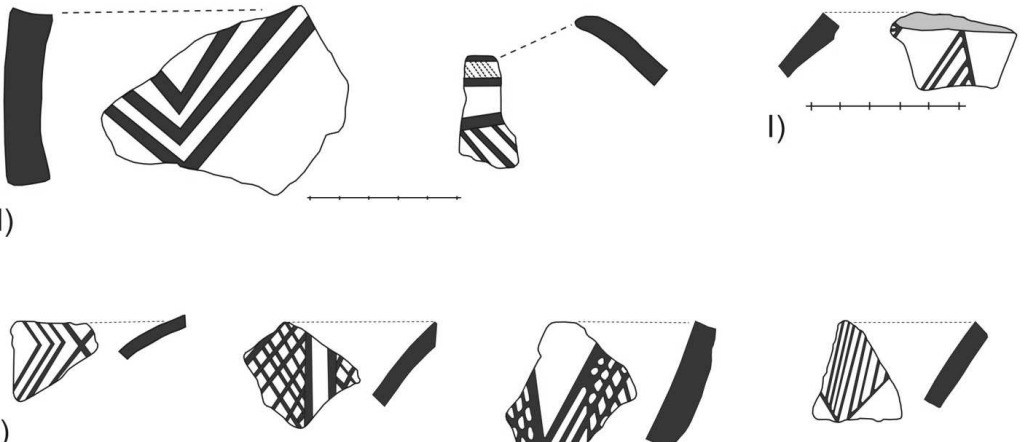

I)

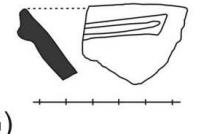

G)
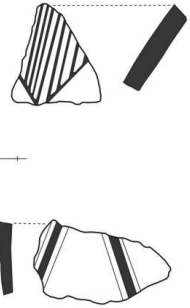

L)

Ryc. 5. Akrotiri. Wybór ceramiki z okresu wczesnocykladzkiego II (wg $\Sigma \omega \tau \eta \rho \alpha \kappa o \pi \circ v ́ \lambda o v$ 2001) Fig. 5. Akrotiri. A selection of the EC II ceramic forms and fragments $(\Sigma \omega \tau \eta \rho \alpha \kappa o \pi \circ v ́ \lambda o v 2001)$

wanych na późną fazę okresu WC II. Nawiązania do tej ceramiki znane są z innych wysp Morza Egejskiego, z Troi oraz Grecji kontynentalnej (Tesalia, Eubea, Attyka) (ryc. 7) ${ }^{23}$.

(d) Na WC II należy datować z pewnością cmentarzysko znajdujące się niedaleko Fira, z grobami skrzyniowymi oraz inwentarzem, na który składają się 4 naczynia (2 ka-

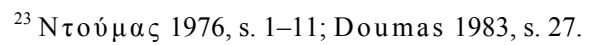



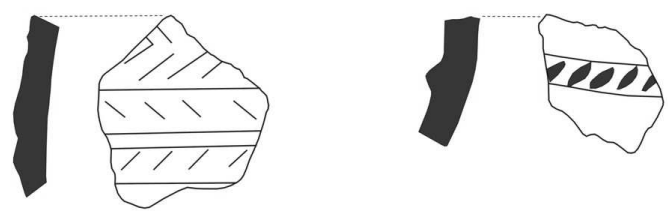

A)

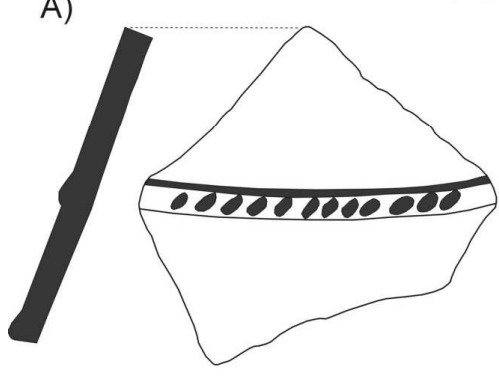

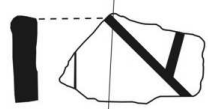

C)
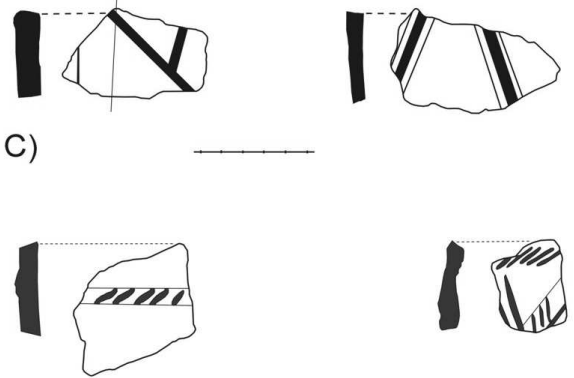

E)

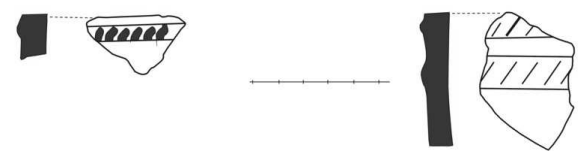

D)
B)
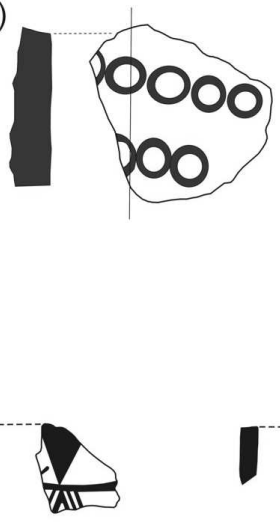

1
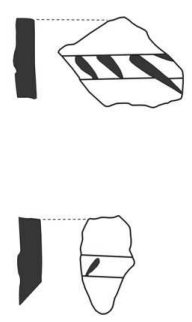

Ryc. 6. Akrotiri. Wybór ceramiki z okresu wczesnocykladzkiego II (wg $\Sigma \omega \tau \eta \rho \alpha \kappa o \pi \circ v ́ \lambda o v$ 2001)

Fig. 6. Akrotiri. A selection of the EC II pottery $(\Sigma \omega \tau \eta \rho \alpha \kappa o \pi \circ v$ vov 2001)

mienne i 2 gliniane). Szkielety wskazują jednoznacznie, że zmarli byli pochowani w tradycji odpowiadającej okresowi WC na Cykladach, tzn. w pozycji z podkurczonymi nogami, na prawym lub lewym boku. Jedno z kamiennych naczyń to steatytowa pyksida, zapewne o proweniencji kreteńskiej, datowana na okres WC II/ wczesnominojski II (WM II) ${ }^{24}$. Jedno z glinianych naczyń (pyksida) pochodzi także z Krety, a dokładniej z Doliny Messary w południowej części wyspy. Datuje się je również na okres WM II ${ }^{25}$.

\footnotetext{
${ }^{24}$ Forsyth 1997, s. 28.

${ }^{25}$ Sakellarakis 1977 , s. 146; Forsyth 1997, s. 28.
} 

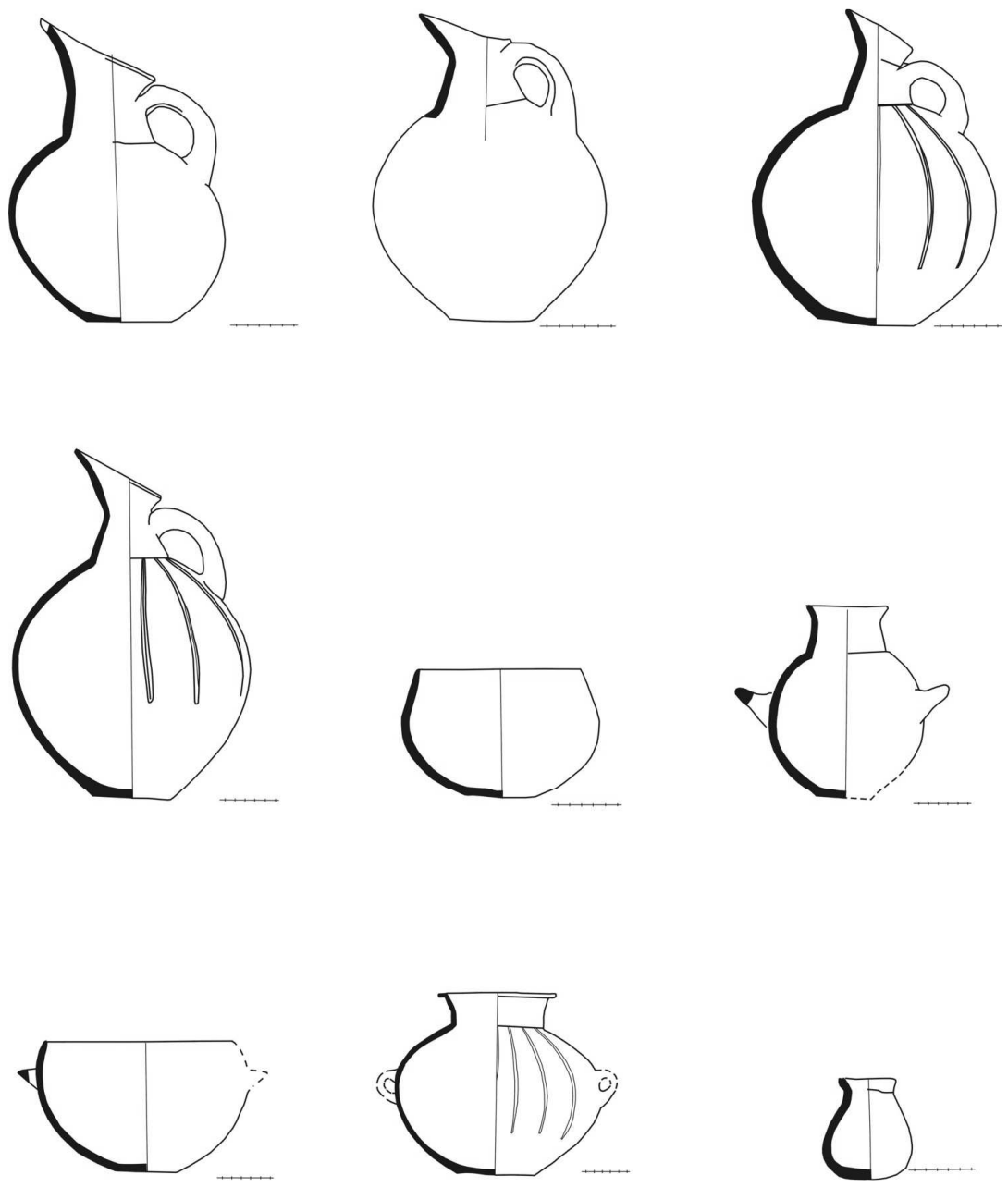

Ryc. 7. Wyspy Christiana. Wybór ceramiki wczesnocykladzkiej II i III) (wg N $\tau$ o v́ $\mu \alpha \varsigma$ 1976)

Fig. 7. Christiana Islands. A selection of the EC II and III pottery (N $\tau$ ov́ $\mu \alpha \varsigma$ 1976)

W tym samym kamieniołomie ponadto odkryto w 1938 r. również 2 słynne marmurowe idole (tzw. harfistów) oraz znalezione wraz z nimi 4 marmurowe naczynia: 2 misy oraz 2 puchary z nóżkami ${ }^{26}$. Ten zestaw odpowiada również kontekstom grobowym, występującym na podobnych cmentarzyskach obszaru cykladzkiego ${ }^{27}$.

Z tego okresu oprócz wyżej opisanych stanowisk pochodzi pewna liczba zabytków luźnych, która ze względu na brak danych o ich pochodzeniu nie może być jednoznacznie przyporządkowana jakiemuś znanemu obiektowi.

${ }^{26}$ Doumas 1983, s. 27.

${ }^{27}$ Forsyth 1997, s. 28; $\Sigma \omega \tau \eta \rho \alpha \kappa o \pi$ ov́dov 2001, s. 99. 
(e) Do tej grupy należy pochodząca z okresu WC II figurka typu ,ze zgiętymi rękami”, którą L. Ross nabył w 1837 r. we wsi Megalochori, a która obecnie znajduje się w Muzeum Narodowym w Kopenhadze. Zapewne pochodziła ona z kontekstu sepulkralnego. Okolice Megalochori są znane z odkryć dużej ilości ceramiki oraz przedmiotów z obsydianu, co sugerowałoby istnienie osady w tym regionie, przynajmniej w okresie WC II.

(f) Niewiadomego pochodzenia jest podobna figurka, o której wspomina C. Renfrew. Podaje on ogólnie, że została znaleziona niedaleko miejscowości Fira, być może na tym samym cmentarzysku, co opisane wyżej ${ }^{28}$.

$\mathrm{Z}$ tego okresu znane są również, nie tylko z Akrotiri, ale także z różnych innych wysp Archipelagu Cykladzkiego, tzw. cykladzkie idole antropomorficzne. W Akrotiri z całego okresu wczesnocykladzkiego odkryto ich w sumie 37, zachowanych w całości lub tylko we fragmentach. Dwadzieścia sześć z nich to tzw. idole schematyczne, a 11 realistyczne wyobrażenia postaci ludzkich. Wiele $\mathrm{z}$ nich odpowiada typom znanym $\mathrm{z}$ innych regionów Cyklad, jednak niektóre z nich, odkryte w Akrotiri, reprezentują nowe typy, charakteryzujące się swoistymi, rzadko występującymi cechami morfologicznymi. Większość z nich datuje się na okres WC I ${ }^{29}$.

W sumie na okres WC II można datować wiele osad rozproszonych po całej wyspie. Znajdowały się one:

- niedaleko miejscowości Fira,

- w pobliżu dzisiejszej wioski Megalochori,

- na Wyspach Christiana,

- na wzgórzu Archangelos,

- w Akrotiri.

Widoczne są w nich bardzo bliskie relacje kulturowe $\mathrm{z}$ innymi regionami basenu Morza Egejskiego. Można tak sądzić nie tylko na podstawie ceramiki, ale również figurek i idoli, które ewidentnie nawiązują do kultury cykladzkiej. Łatwo zauważyć, że już $\mathrm{w}$ tym okresie wyspa Thira odgrywała jedną $\mathrm{z}$ czołowych ról w wymianie. Ten stan rzeczy pozwalał zapewne na bogacenie się lokalnej społeczności, co jest uchwytne w kontekstach grobowych. Wiodące znaczenie miało z całą pewnością osiedle Akrotiri, które z małej neolitycznej wioski uległo transformacji w silną osadę.

\subsection{Okres wczesnocykladzki III (WC III) (2300-2000 p.n.e.)}

Okres WC III dzieli się na dwa podokresy: WC III A i WC III B. W tym opracowaniu jednakże będzie traktowany jako jedna całość (WC III), ze względu na fakt, że brak jest materiałów archeologicznych, które mogłyby być bezpośrednio przypisane konkretnej podfazie.

\footnotetext{
${ }^{28}$ Renfrew 1969, s. 20; 1972, s. 425; Forsyth 1997, s. 28.

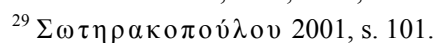


Wyspa Thira i jej dość ubogie osadnictwo z poprzedniego okresu weszła w okres WC III bardzo płynnie ${ }^{30}$. Cyklady w poprzedniej fazie przeżywały swój rozkwit, a i na wyspie Thirze dokonywał się ów proces. Jednakże z początkiem okresu WC III na Cykladach nastąpiło załamanie kulturowe, którego przyczyny nie można jednoznacznie ustalić. Doszło wówczas do opuszczenia większości osad na wyspach, a całe życie skupiło się jedynie w kilku wielkich osiedlach o charakterze miejskim, w pewnych rejonach Archipelagu. Należy jednak podkreślić, że Thira nie podlegała wówczas bezpośrednio tym wszystkim przemianom, jakie zachodziły gdzie indziej. Pomimo że model osadniczy na wyspie był bardzo podobny do cykladzkiego, jednak pewne czynniki miały istotny wpływ na ukształtowanie własnego typu osadnictwa, którego prawie nie spotyka się gdzie indziej z tego czasu.

Na okres WC III datuje się zatem osadę w (a) Akrotiri, (b) cmentarzysko w kamieniołomie Karageorgis oraz (c) materiał z wąwozu Kalamia.

(a) Najbardziej znaczące pozostałości z okresu WC III zostały odkryte podczas badań stanowiska Akrotiri. Pochodzą z niego liczne konstrukcje architektoniczne, które zalegają pod budowlami dwu- lub trzypiętrowymi z okresów późniejszych. Są dwa typy tych struktur:

(A) prostokątne budowle ziemiankowe $\mathrm{z}$ fundamentami osadzonymi bezpośrednio w skale macierzystej,

(B) komory wydrążone w tej skale ${ }^{31}$.

Na podstawie zarejestrowanego $\mathrm{w}$ nich materiału ceramicznego (bardzo często zachowane w całości naczynia) można datować te kompleksy na okres WC III (ryc. 8-12). Większość tych znalezisk odkryto jednakże w kontekście późnego brązu, co można interpretować na dwa sposoby: starsze materiały mogły trafić tu podczas wykonywania wykopów pod fundamenty przyszłych budowli bądź przedmioty z wczesnych faz były nadal w użyciu podczas okresu późnocykladzkiego I (PC I $)^{32}$.

(A) Do pierwszego, wzmiankowanego wyżej typu konstrukcji należą m.in. 2 prostokątne pomieszczenia, położone jedno obok drugiego, odseparowane od siebie niewielkim murem. Ich podłoga była wykonana $z$ ubitych fragmentów lawy wulkanicznej o czerwonym odcieniu ${ }^{33}$. Na podłodze zalegała warstwa ziemi barwy czarnej, z intensywnymi śladami spalenizny. W literaturze ów kompleks zwany jest powszechnie - za

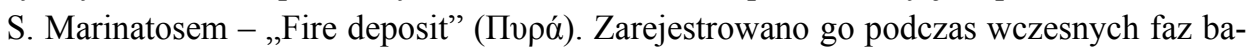
dań na stanowisku Akrotiri, w rejonie na wschód od Kompleksu Delta ${ }^{34}$. W nim także, oprócz wielu naczyń i fragmentów ceramicznych ${ }^{35}$, odkryto między innymi andezytowy

\footnotetext{
${ }^{30}$ Doumas 1983, s. 27.

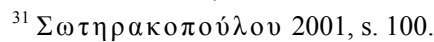

${ }^{32} \Sigma \omega \tau \eta \rho \alpha \kappa о \pi о и ́ \lambda$ ov 2001, s. 101.

${ }^{33}$ Marinatos 1971, s. 21, tabl. 22: 1.

${ }^{34}$ Marinatos 1971, s. 19-24; M $\alpha \rho \theta \dot{\alpha} \rho \eta$ 2001, s. 112.

${ }^{35}$ Marinatos 1971, ryc. 2-9; tabl. 22: 2.
} 


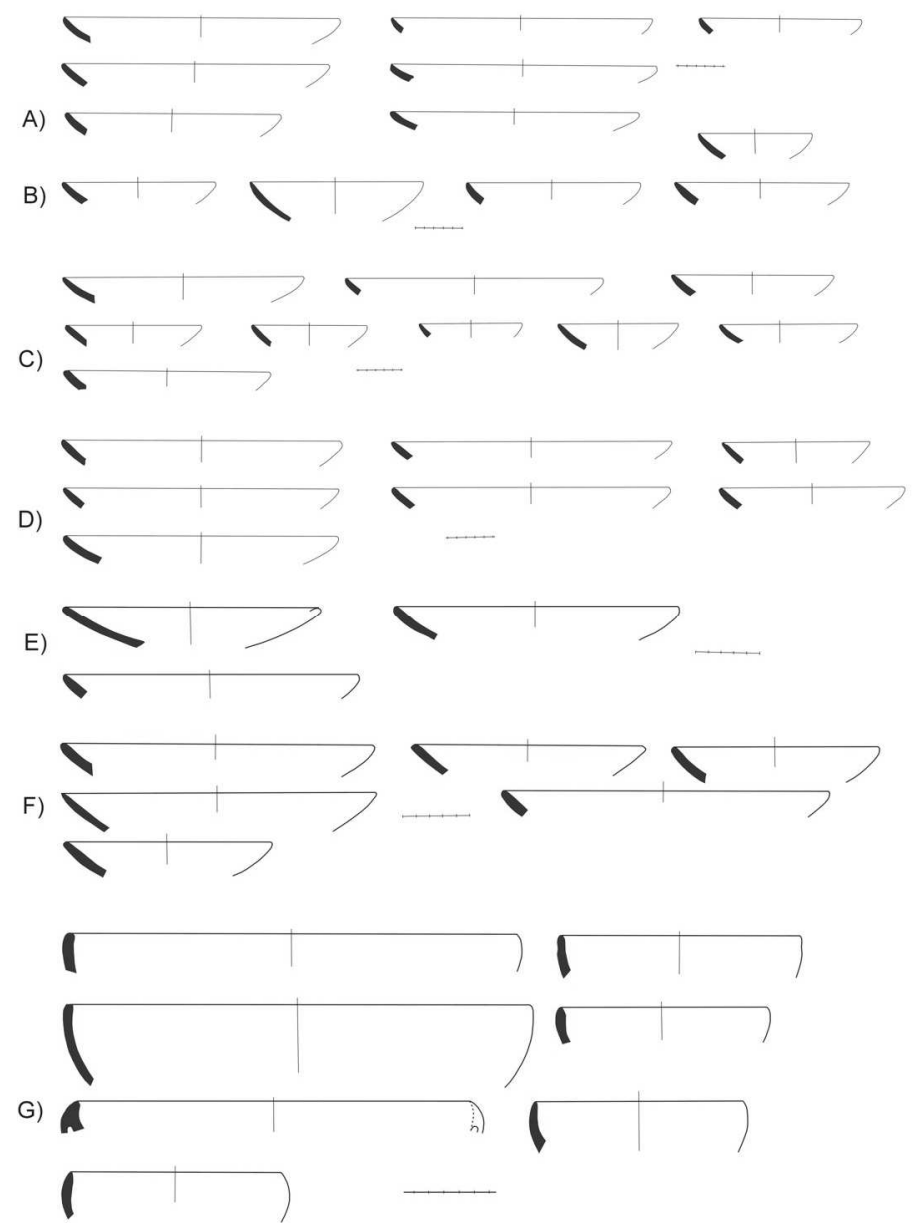

Ryc. 8. Akrotiri. Wybór ceramiki z okresu WC III (wg $\Sigma \omega \tau \eta \rho \alpha \kappa o \pi \circ v ́ \lambda \circ v 2001$ )

Fig. 8. Akrotiri. A selection of the EC III pottery cont. ( $\Sigma \omega \tau \eta \rho \alpha \kappa \circ \pi \circ v$ $\lambda$ ov 2001)

piec, kilka ułamków obsydianu melijskiego ${ }^{36}$, dwie niewielkie części stopionego ołowianego naczynia oraz trzy szpile z brązu, charakterystyczne dla obszaru Cyklad we wczesnej epoce brązu (WEB). Godne uwagi są jeszcze dwa niewielkie figurki ceramiczne $\mathrm{z}$ wizerunkami wołów ${ }^{37}$ oraz konkrecja obsydianu o długości pół metra ${ }^{38}$.

(B) Drugim typem konstrukcji są wspomniane wyżej, wycięte w skale komory, które zlokalizowano w przynajmniej czterech miejscach na osadzie. W dwóch przypadkach stwierdzono bez wątpienia ich magazynowy charakter, z bardzo długą rozpiętością chro-

\footnotetext{
${ }^{36}$ Marinatos 1971, s. 20.

${ }^{37}$ Marinatos 1971, s. 21, tabl. 21: 2.

${ }^{38}$ Marinatos 1971 , s. 23, ryc. 10.
} 
nologiczną - od końca WC III/pocz. środkowej epoki brązu (ŚEB) do późnej epoki brązu (PEB). Do takich miejsc należy bez wątpienia pomieszczenie 3 Domu Dam, pod którego podłogą zarejestrowano tego typu obiek $\mathrm{t}^{39}$. Odkryto w nim naczynia środkowocykladzkie (ŚC), z wyraźnymi śladami prażenia oraz pozostałości węgli. Różnie interpretuje się charakter tych naczyń. Najbardziej kuriozalny jest zaproponowany przez grecką archeolog A. Papagiannopoulou, która uważa, że owe pojemniki to pamiątki rodowe, a ślady działania ognia na ich powierzchniach świadczą o ich rytualnym „odkażaniu", które odbywało się w podobnych jamach ${ }^{40}$. W drugiej hipotezie założono, że chodzi

A)
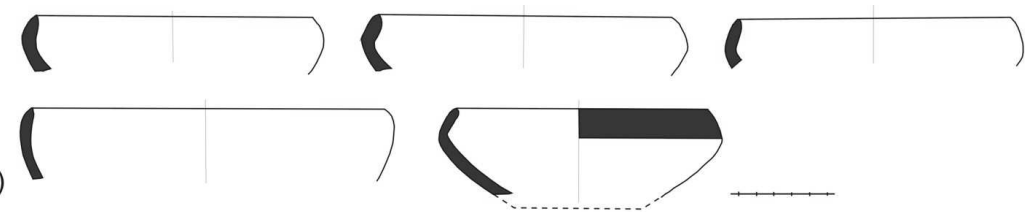

B)

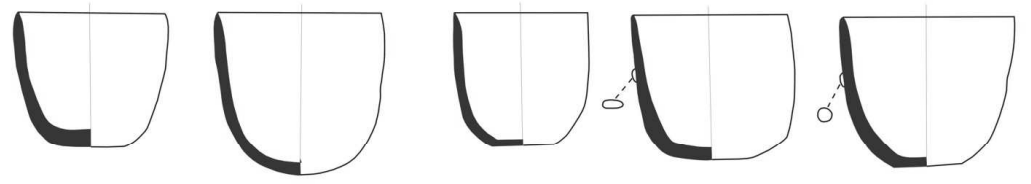

C)
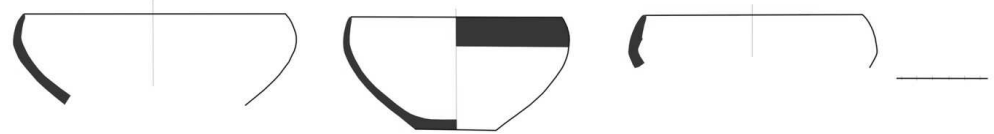

D)
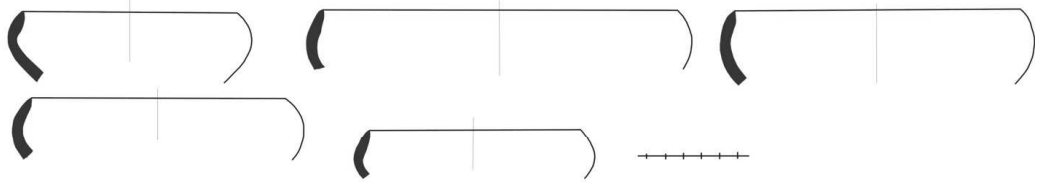

E)

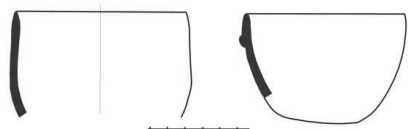

F)

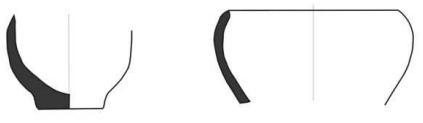

G)

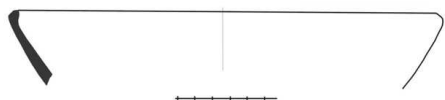

H)

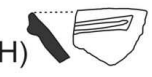

Ryc. 9. Akrotiri. Wybór ceramiki z okresu WC III (wg $\Sigma \omega \tau \eta \rho \alpha \kappa o \pi \circ v ́ \lambda o v$ 2001)

Fig. 9. Akrotiri. A selection of the EC III pottery cont. ( $\Sigma \omega \tau \eta \rho \alpha \kappa o \pi \circ v i \lambda o v 2001)$

\footnotetext{
${ }^{39} \mathrm{~N} \tau$ ov́ $\mu \alpha \varsigma$ 1987, s. 251, 252.

${ }^{40}$ Papagiannopoulou 1991, s. 29, 33, 34.
} 
A)
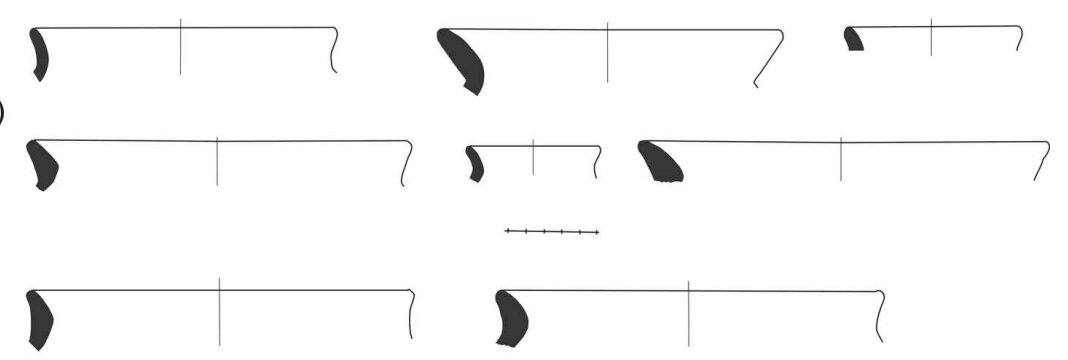

B)

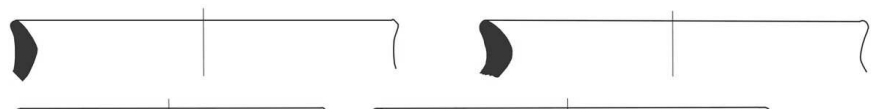

B) 12 ?

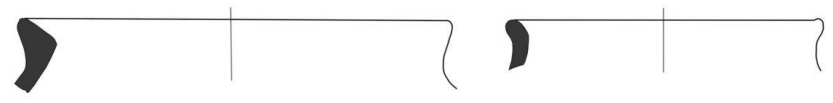

))
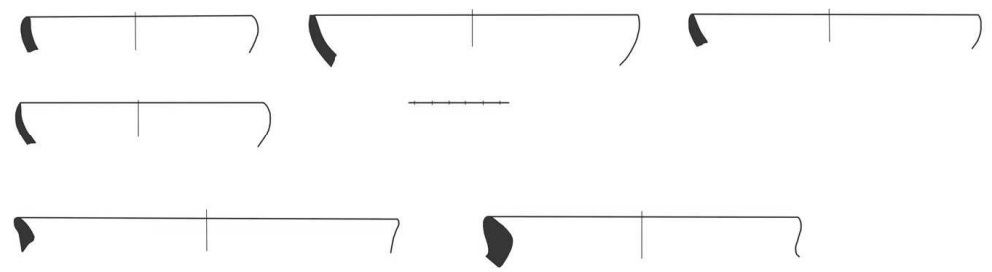

D)

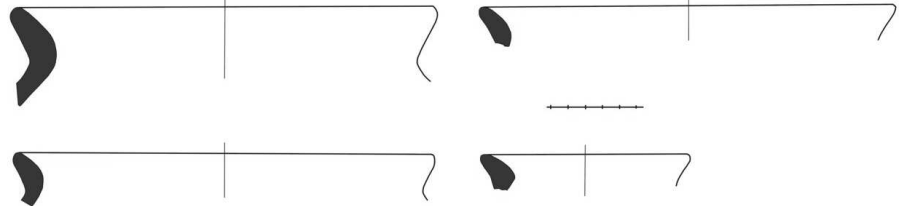

Ryc. 10. Akrotiri. Wybór ceramiki z okresu WC III (wg $\Sigma \omega \tau \eta \rho \alpha \kappa o \pi$ o v́

Fig. 10. Akrotiri. A selection of the EC III pottery, cont. $(\Sigma \omega \tau \eta \rho \alpha \kappa o \pi \circ v$ íov 2001)

o jamy wykorzystywane przez pradziejowych wytwórców do przechowywania i oczyszczania gliny, na co wskazują pozostałości tego materiału w zagłębieniach ${ }^{41}$. Równocześnie istnieje pogląd o sepulkralnym wykorzystywaniu wspomnianych jam ${ }^{42}$.

(b) Innym stanowiskiem $\mathrm{z}$ tego okresu jest cmentarzysko złożone $\mathrm{z}$ około 12 grobów, zlokalizowane w kamieniołomie Karageorgis, na brzegu kaldery, pomiędzy miejscowościami Fira i Athinios. Groby te zostały odkryte przez ciężki sprzęt budowlany. Udało się zbadać tylko jeden $\mathrm{z}$ nich. Zarejestrowano $\mathrm{w}$ nim ceramikę identyfikowaną z okresami WC III B do ŚC, łącznie z naczyniem z ornamentem geometrycznym (Geometric Ware), który jest bardzo charakterystyczny i dystynktywny dla okresu WC III B ${ }^{43}$.

\footnotetext{
${ }^{41} \Sigma \omega \tau \eta \rho \alpha \kappa о \pi \circ v ́ \lambda$ ov 2001, s. 101; M $\alpha \rho \theta \alpha \dot{\rho} \eta$ 2001, s. 112.

${ }^{42}$ Doumas 1985, s. 173, 174; M $\alpha \rho \theta \alpha \dot{\rho} \eta 2001$, s. 112.

${ }^{43}$ Forsyth 1997, s. 29.
} 
A)
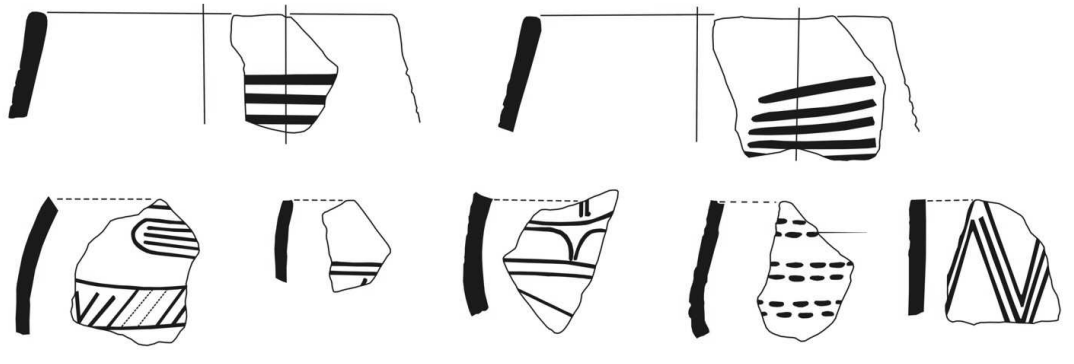

I边I进

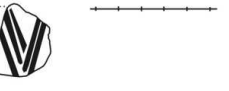

B)
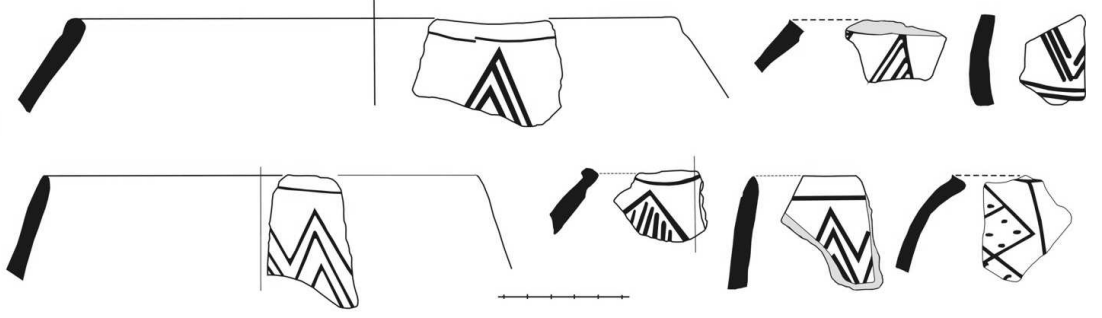

C)

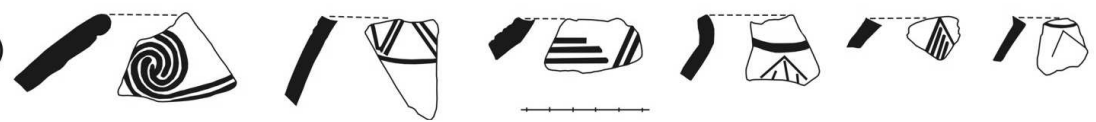

Ryc. 11. Akrotiri. Wybór ceramiki z okresu WC III (wg $\Sigma \omega \tau \eta \rho \alpha \kappa o \pi o v ́ \lambda o v$ 2001)

Fig. 11. Akrotiri. A selection of the EC III pottery, cont. ( $\Sigma \omega \tau \eta \rho \alpha \kappa o \pi \circ v$ $\lambda \circ v 2001)$

(c) W wąwozie Kalamia, niedaleko Faros na Półwyspie Akrotiri, na początku lat 70. $\mathrm{XX}$ w. przeprowadzono badania powierzchniowe, podczas których znaleziono liczne fragmenty ceramiczne, datowane na okres WC III. Wiele z nich pochodziło z górnej partii naczynia zasobowego (pitosu grobowego), na którego dnie zalegały kości czaszki noworodka ${ }^{44}$.

Podsumowując cały okres wczesnocykladzki, można wyciągnąć następujące wnioski. Podczas WEB wyspa Thira ze skromnych swych późnoneolitycznych początków (osada rybacka?) wyrosła w początkowej fazie WEB na znaczący węzeł w kwitnącej sieci kontaktów na obszarze basenu Morza Egejskiego. W okresie WC II mieszkańcy wyspy Thiry brali udział w wymianie $\mathrm{z}$ innymi ośrodkami na Cykladach, dzięki czemu zaczęli coraz lepiej prosperować, co jest czytelne w zwiększającym się coraz bardziej materiale archeologicznym. Wydaje się, że w okresie WC III na Thirze uniknięto zała-

${ }^{44} \Sigma \omega \tau \eta \rho \alpha \kappa o \pi$ ov́dov 2001, s. 100. 
mania osadniczego, jakie w tym czasie jest czytelne na innych Wyspach Cykladzkich. Pod koniec tego okresu (WC III B) na wyspie wyrosło wielkie centrum, które mieściło się w południowej jej części, w pobliżu dzisiejszej wsi Akrotiri. Był to zapewne największy ośrodek handlu na wyspie, mający liczne kontakty z innymi obszarami Morza Egejskiego (Kreta, Wyspy Cykladzkie, Grecja kontynentalna itd.), dowiedzione na podstawie ceramiki miejscowej, jak i pochodzącej z różnych części tego obszaru. W takiej oto kondycji wyspa Thira weszła w środkową epokę brązu (ŚEB) na Cykladach, zwaną także w literaturze okresem środkowocykladzkim $\left({ }^{\mathrm{S} C}\right)^{45}$.

A)
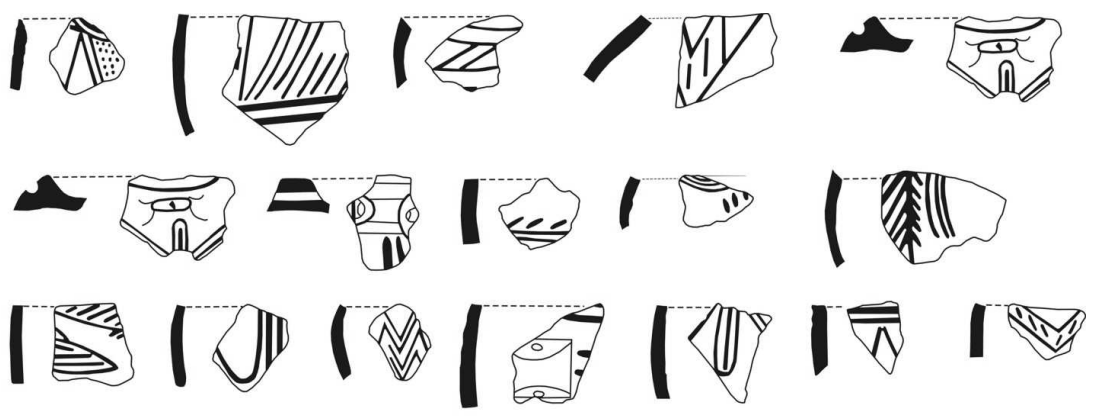

B)

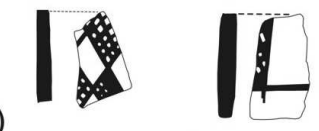

I文 InI

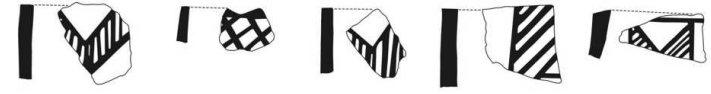

Sotir. 45

C)

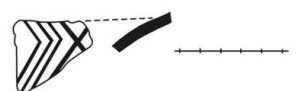

D)
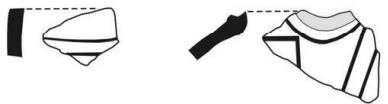

IVI

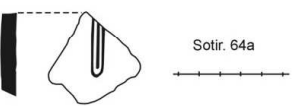

E)
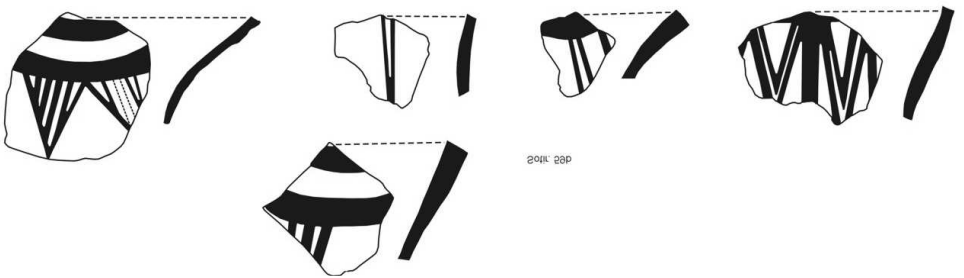

Ryc. 12. Aktotiri. Wybór ceramiki z okresu WC III (wg $\Sigma \omega \tau \eta \rho \alpha \kappa \circ \pi$ ov́ $\lambda$ ov 2001)

Fig. 12. Akrotiri. A selection of the EC III pottery, cont. ( $\left.\Sigma \omega \tau \eta \rho \alpha \kappa o \pi \circ v \lambda_{0} v 2001\right)$

${ }^{45}$ Forsyth 1997, s. 30. 


\section{WYSPA THIRA W ŚRODKOWEJ EPOCE BRĄZU (ŚEB) (2000-1600 p.n.e.) (por. ryc. 1 i tab. 2)}

Zważywszy na fakt, że nie jest możliwe dokładne określenie cezury między WEB i ŚEB (wiele danych archeologicznych nakłada się na siebie w sensie czasowym oraz typologicznym), niektóre stanowiska, które zostaną teraz przedstawione, mogą należeć jeszcze do poprzedniego okresu albo stanowić początek niniejszego. Innymi słowy ich datowanie może przypadać na czas pomiędzy końcem WEB a początkiem ŚEB.

Do tego okresu, a głównie do jego początku, zaliczono stanowiska, których stosunkowo dobry stopień zbadania pozwala na nakreślenie obrazu lokalnego osadnictwa, relacji społeczno-ekonomicznych oraz powiązań zewnętrznych wyspy, w interesującym nas czasie. Są to następujące stanowiska: (a) w Akrotiri, (b) znana już z poprzedniego okresu osada we Ftellos (kamieniołom Chiotopoulos), (c) osada w kamieniołomie Mavromatis oraz (d) nekropolia w miejscowości Agios Ioannis Eleimon (kamieniołom Karageorghis).

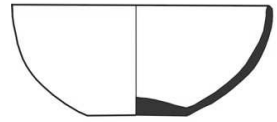

$\stackrel{5}{+} \quad 10 \mathrm{~cm}$

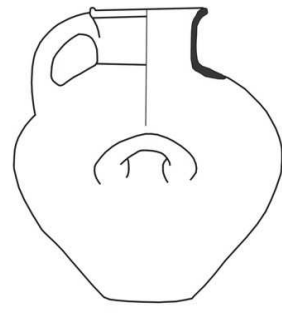

$\stackrel{5}{10 \mathrm{~cm}}$

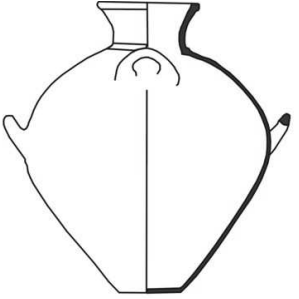

i. $5 . \quad 15 \mathrm{~cm}$

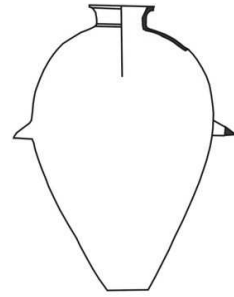

$\stackrel{5}{+5}+15 \mathrm{~cm}$

Ryc. 13. Akrotiri. Formy ceramiczne z okresu ŚC (wg Dou mas 1983)

Fig. 13. Akrotiri. A selection of the MC ceramic forms (Dou mas 1983)

(a) Ślady zasiedlenia wyspy również w tym okresie zostały stwierdzone na osadzie Akrotiri, gdzie zaobserwowano kontynuację osadnictwa. Są to jedynie materiały ceramiczne (ryc. 13), ponieważ jak dotychczas brak na omawianej osadzie danych świadczących o istnieniu założeń architektonicznych czy też sepulkralnych z wczesnego okresu ŚC [ŚC I (2000-1900 p.n.e.)] - Okres Starszych Pałaców na Krecie. Liczne ślady z okresu późnego ŚC [ŚC II-III (ok. 1900-1600 p.n.e.)] - Okres Nowych Pałaców na Krecie - zostały odkryte w kilku punktach na osadzie. Do takich miejsc należy Dom Zachodni. Właśnie w nim podczas zakładania wykopu sondażowego w północno-zachodnim narożniku natknięto się na dwumetrowej długości ścianę, która zalegała niżej niż Dom Zachodni, a na podstawie ceramiki została wydatowana na okres $\mathrm{S}^{46}$.

${ }^{46} \mathrm{~N} \tau$ ov́ $\mu \alpha \varsigma$ 1985, s. 169, 170; Forsyth 1997, s. 34. 
Podczas innych badań sondażowych, poczynionych wzdłuż południowej i wschodniej ściany tej budowli, ujawniono kolejne fragmenty ścian, które na podstawie ceramiki datuje się na $S^{S}{ }^{47}$. Na potwierdzenie ustaleń otwarto również tego typu sondaże w podłogach pomieszczeń 3A i 6 tego samego założenia, datowanych na PC. Tutaj też zaobserwowano ściany z wcześniejszego okresu $\mathrm{SC}^{48}$.

Podobne ślady zabudowy z ŚC odsłonięto m.in. w okolicach Pomieszczenia 15 i Pomieszczenia 3 Kompleksu Delta. W niektórych przypadkach okazało się, że budowle z okresu PC I zostały wzniesione na fundamentach pochodzących z okresu ŚC III ${ }^{49}$. W niektórych wykopach sondażowych zarejestrowano także fragmenty tynku noszące ślady malowania monochromatycznego bądź prostych motywów geometrycznych ${ }^{50}$.

Ceramika pozyskana z sondaży, jak i szybów pod podstawy słupów podtrzymujących dach nad placem wykopalisk pochodzi głównie z okresu ŚC: ciemna polerowana (Dark Burnished), cykladzka biała (Cycladic White), czarno-czerwona (Black-and-Red). Występują tu także liczne fragmenty naczyń importowanych z Grecji kontynentalnej oraz Krety.

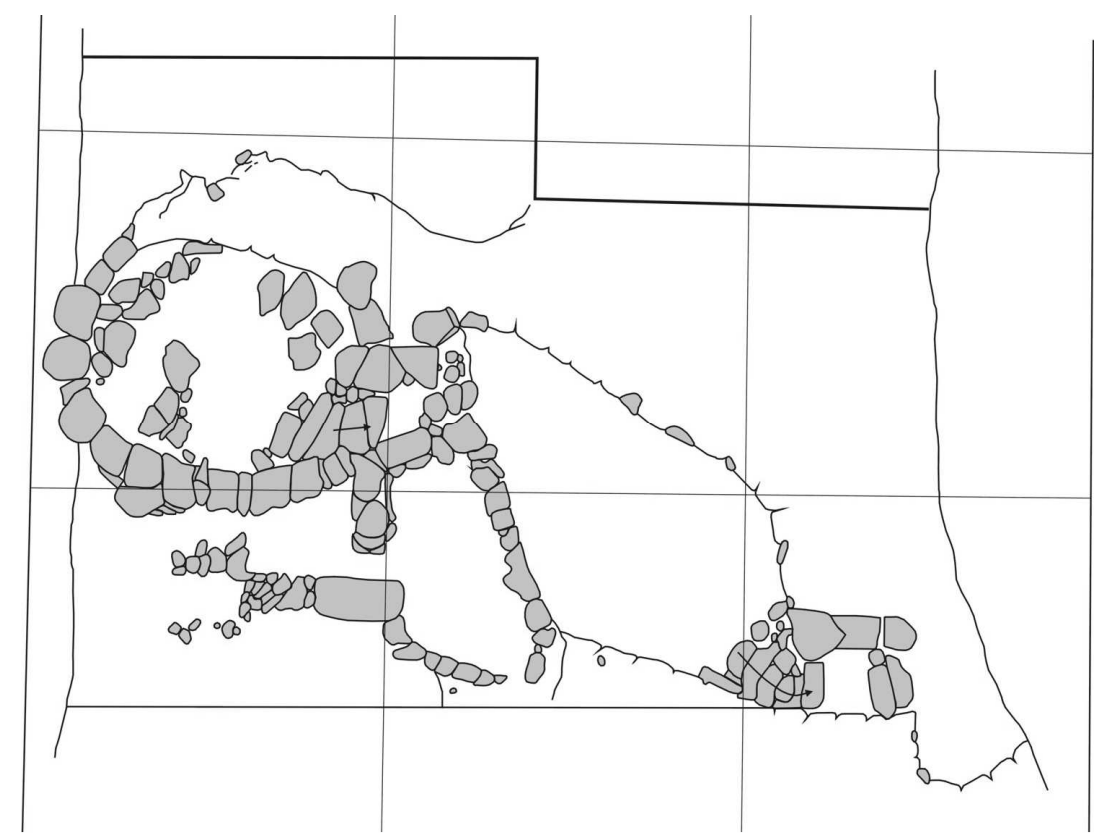

Ryc.14. Ftellos. Zarys obiektu (wg M $\alpha \rho \theta \alpha \rho \eta 1983)$

Fig. 14. Ftellos. An outline of the structure (M $\alpha \rho \theta \alpha \rho \eta 1983)$

${ }^{47} \mathrm{~N} \tau$ ov́ $\mu \alpha \varsigma$ 1990, s. 232, 233.

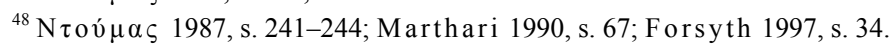

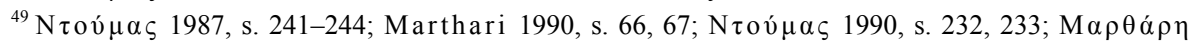
2001, s. 113

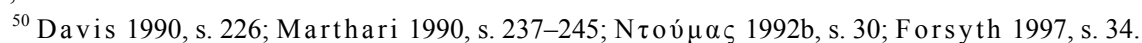


(b) Jednym z najbardziej dystynktywnych stanowisk była osada położona niedaleko Ftellos, około $1 \mathrm{~km}$ na południe od miasta Fira. Tutaj w kamieniołomie PapageorgiouChiotopoulos, podczas prac przy urobku pumeksu, natknięto się na początku lat 80 . $\mathrm{XX}$ w. na elementy architektoniczne związane z przynajmniej kilkoma budowlami. Większość z nich została silnie zniszczona podczas eksploatacji kamieniołomu. Tylko jedna $\mathrm{z}$ nich została $\mathrm{w}$ zadowalającym stopniu zbadana archeologicznie (ryc. 14). Na podstawie pozyskanej ceramiki, jak i innych przesłanek można ją datować na wczesną ŚEB na Cykladach (ŚC I) (ryc. 15). Badanie tego obszaru zostało zainicjowane przez niemieckiego wulkanologa Waltera Friedricha odkryciem fragmentów ceramicznych datowanych na wczesną ŚEB, podczas pomiaru grubości warstwy pumeksu zalegającego na wyspie, pochodzącego z wybuchu w $\mathrm{PEB}^{51}$. Natychmiast podjęto badania ratownicze, których wynikiem było odkrycie (ryc. 14) trzech owalnych w rzucie pomieszczeń oraz jednego o nieokreślonym kształcie. To ostatnie było zniszczone przez prace wydobywcze pumeksu w tym kamieniołomie. Całość była wkopana w warstwę pochodzącą z materiału erupcyjnego Cape Riva (CR). Jej orientacja przebiegała na linii północny zachód - południowy wschód.
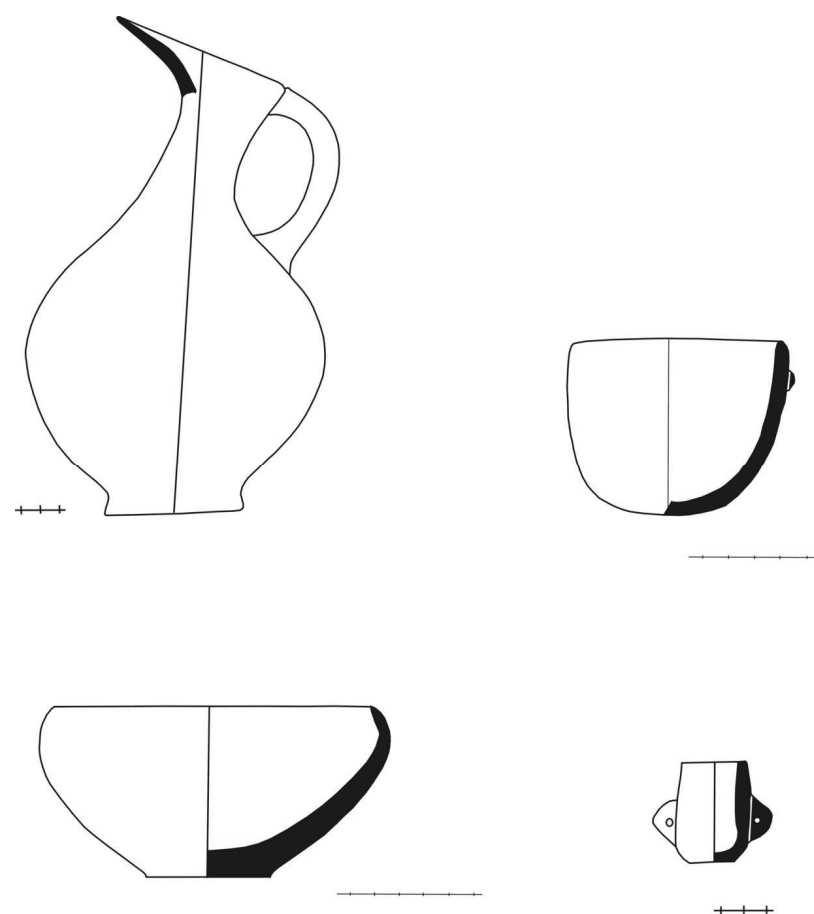

Ryc. 15. Ftellos. Wybór ceramiki (wg M $\alpha \rho \theta \alpha \dot{\rho} \eta$ 1983)

Fig. 15. Ftellos. A selection of pottery (M $\alpha \rho \theta \alpha \dot{\alpha} \eta$ 1983)

${ }^{51}$ Friedrich 2000, s. 140, 141. 


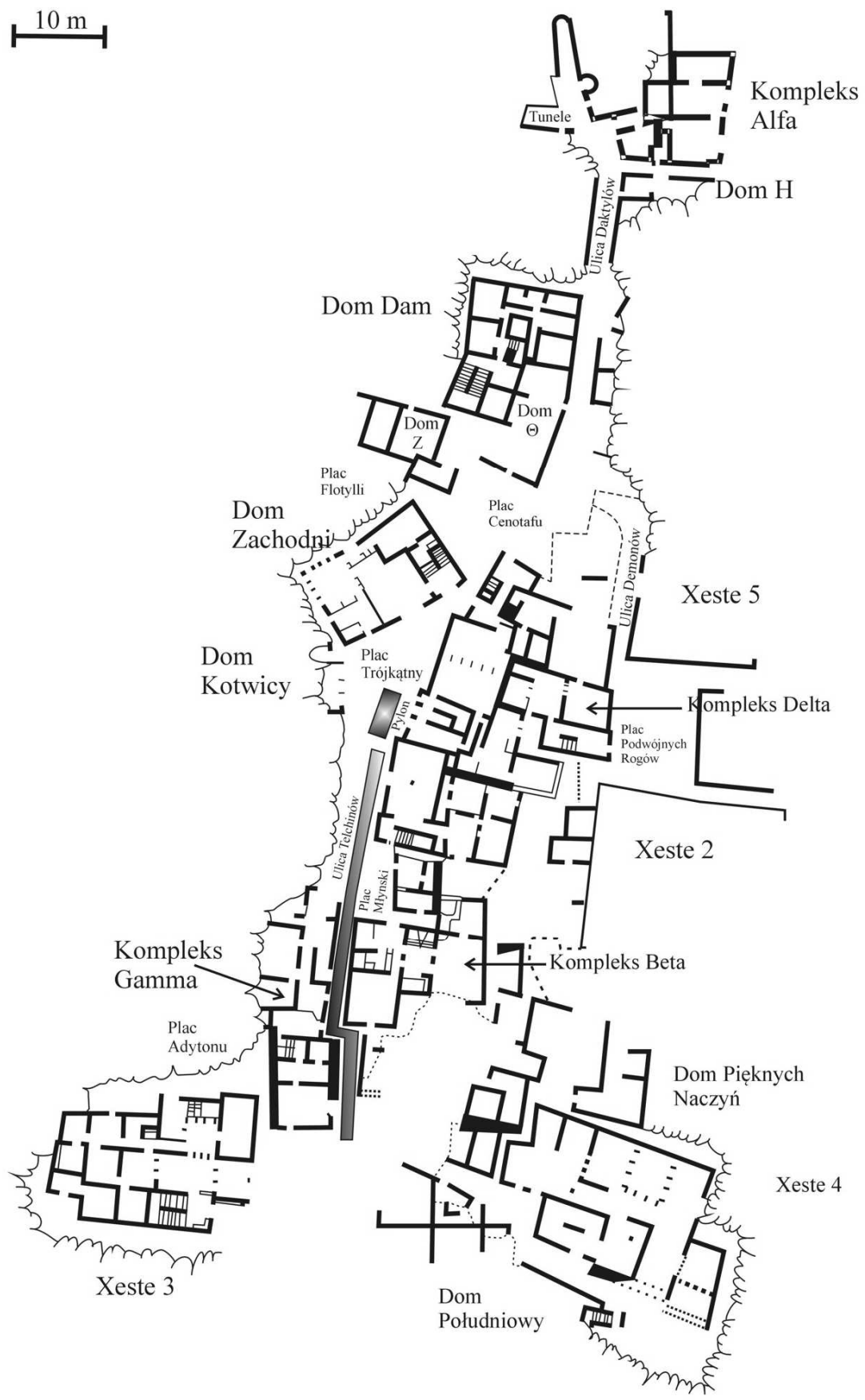

Ryc. 16. Plan miasta Akrotiri w PEB (wg For syth 1997 z modyfikacjami)

Fig. 16. An outline of the town of Akrotiri (Forsyth 1997 with modifications) 
Pomieszczenie I miało przekrój elipsoidalny, o wymiarach po najdłuższych osiach 3,70 i 3,10 m. Jedna $\mathrm{z}$ jego ścian zachowała się w niektórych miejscach do wysokości 3,40 m. Podłoga natomiast była wyłożona nieregularnymi płytami, wykonanymi z zastygłej lawy wulkanicznej, a miejsca złączeń zamazano rozrzedzoną gliną.

Pomieszczenie I zostało połączone z pomieszczeniem II przejściem ze stopni kamiennych, mimo że nie ma wielkich różnic w poziomach podłóg obu pomieszczeń. Należy zatem sądzić, że te stopnie nie pełniły roli schodków, ale miały za zadanie wzmocnienie konstrukcji ścian, ponieważ te dwa pomieszczenia są dość obszerne i nie ma w nich jakichkolwiek ścian działowych lub podpór. Wypełnisko stanowił w dużej mierze materiał pochodzący z obwału górnych partii ścian oraz ceramika znajdująca się na różnych poziomach, co pozwala na przypuszczenie, że pierwotnie musiała ona być umieszczona na swego rodzaju półkach bądź innych elementach zabudowy wnętrza ${ }^{52}$.

Pomieszczenie II znajdujące się w centrum budowli było o przekroju romboidalnym i miało rozmiary 6,40 i $3,40 \mathrm{~m}$.

Pomieszczenie III zapewne było podobne w przekroju do pomieszczenia I, jednak stopień zniszczeń nie pozwala jednoznacznie określić jego rozmiarów. Zachowała się tylko jedna ściana, wzniesiona z kamieni. Materiał zalegający w wypełnisku reprezentowany jest przez ceramikę datowaną na koniec okresu WC III i początek ŚC I.

We wczesnych fazach badania Ftellos sądzono, że owe konstrukcje miały charakter grobowy, ale brak jakiegokolwiek materiału kostnego nie pozwala utrzymać tego założenia. Raczej należy sądzić, że jest to fragment większego kompleksu budowli, którego rozmiarów, ze względu na zalegającą grubą warstwę pumeksu (ok. $35 \mathrm{~m} \mathrm{w}$ tym miejscu) oraz na zniszczenia, spowodowane działalnością wydobywczą, nie sposób jednoznacznie określić. Ten typ zabudowy ma analogie, chociaż o mniejszych rozmiarach, we wnętrzu osady odkrytej na Wyspach Christiana, a wiązanej z grupą Kastri (WC III B).

(c) Innym miejscem kryjącym pozostałości założeń architektonicznych oraz liczne fragmenty ceramiczne $\mathrm{z}$ interesującego nas okresu jest osada i być może niewielkie cmentarzysko (kilka grobów), których ślady zostały odkryte podczas prac ratowniczych w kamieniołomie Mavromatis. Kamieniołom ten położony jest niedaleko Akrotiri, na skraju kaldery. Do reliktów architektonicznych zalicza się mury należące do dwóch niezależnych kompleksów. W toku badań zarejestrowano liczne fragmenty ceramiczne, które datują te stanowiska na okres wczesnocykladzki oraz późnocykladzki IA ${ }^{53}$.

(d) Na nekropolii w Agios Ioannis Eleimon w 1978 r. pod kierownictwem archeologa X. Sigala. Duży stopień zniszczeń grobów na tym cmentarzysku pozwolił tylko na zbadanie niektórych z nich. Zawartość poszczególnych grobów była podobna. Wszystkie groby były komorowe, prawdopodobnie założone na planie okręgu, w których zarejestrowano liczne fragmenty kości ludzkich, ceramikę oraz inne przedmioty, zalegające pod $20 \mathrm{~cm}$ warstwą wypełniska. W jednym z grobów udało się stwierdzić pochówek trzech zmar-

\footnotetext{
${ }^{52} \mathrm{M} \alpha \rho \theta \alpha \dot{\rho} \eta 2001$, s. $110-120$.

${ }^{53}$ T $\varepsilon \lambda \varepsilon \beta \dot{\alpha} v \tau$ ov 1982 , s. 358,$359 ; 1987$, s. 509-512.
} 
łych $^{54}$. Tamtejsza ceramika głównie datowana jest na przełom WC III/ŚC I i posiada liczne analogie z osady cykladzkiej w Phylakopi I, zwłaszcza z końcowej fazy zasiedlenia tzw. Pierwszego Miasta i z początków zasiedlenia Drugiego Miasta ${ }^{55}$.

Model osadniczy na Thirze różnił się zasadniczo od panującego na Cykladach, gdzie nastąpiło opuszczenie małych ośrodków i powstanie pojedynczych, rozległych osiedli. Czołowym ośrodkiem, mającym paralele w dużych założeniach na wyspach (np. Filakopi na Milos) było miasto Akrotiri ${ }^{56}$. Być może właśnie te niewielkie osady, które istniały w bezpośrednim sąsiedztwie Akrotiri we wcześniejszych okresach, zostały teraz ostatecznie wchłonięte przez owo centrum.

W omawianym okresie (ŚC) funkcjonowały w sumie dwa centra osadnicze na wyspie Thira:

- zachodnie, ze stanowiskami Ftellos i Agios Ioannis Eleimon, rozwijającymi się na krawędzi kaldery,

- południowe, do którego należy miasto Akrotiri.

$\mathrm{Na}$ powstanie zachodniego centrum duży wpływ zapewne miały naturalne walory obronne, jakie dawała stroma, niedostępna ściana kaldery. Charakteryzowała się ona jednakże jeszcze jedną wartościową cechą: w jej ścianach znajdowały się niewielkie wychodnie rud mineralnych, jak: ołowiu, żelaza, talku, azurytu oraz malachitu. W. L. Friedrich i C. Doumas uważają, że dostęp do tych bogactw naturalnych istniał z całą pewnością w okresie PC I, ale nie jest wykluczona ich wcześniejsza eksploatacja ${ }^{57}$. Południowe centrum (z osadą Akrotiri wraz z portem) skupiało się na handlu i kontaktach zamorskich, ze względu na swe dogodne, dobrze chronione położenie ${ }^{58}$. Ten stan rzeczy jednakże istniał w ŚC I i II. W ŚC III model osadniczy uległ częściowej zmianie. Stanowiska położone przy kalderze opustoszały. Wydaje się, że osada Ftellos nie istniała już w początkach ŚEB, natomiast druga osada zanikła w późnej fazie ŚEB. W tym okresie również powstało inne osiedle na południu, niedaleko Megalochori.

Na podstawie zbadanego cmentarzyska w Agios Ioannis Eleimon można w przybliżeniu określić także zwyczaje grzebalne panujące w tym czasie na wyspie. Groby komorowe miały niemal kolisty kształt $\mathrm{w}$ rzucie. Wycinane były w stosunkowo miękkim podłożu. Kryły zazwyczaj kilka pochówków, co może wskazywać na rodzinny charakter każdej mogiły ${ }^{59}$.

Życie społeczno-gospodarcze na wyspie w okresie od WC III do ŚC rozwijało się w następujących sferach:

- rolnictwo oraz hodowla bydła na urodzajnych, wulkanicznych glebach półwyspu Akrotiri,

\footnotetext{
${ }^{54} \mathrm{M} \alpha \rho \theta \alpha \dot{\rho} \eta$ 2001, s. 110.

${ }^{55} \mathrm{M} \alpha \rho \theta \alpha \dot{\alpha} \eta 2001$, s. 110, 111.

${ }^{56} \mathrm{M} \alpha \rho \theta \alpha \dot{\alpha} \rho \eta 2001$, s. 114.

${ }^{57}$ Friedrich, Doumas 1990, s. 502, 503.

${ }^{58} \mathrm{M} \alpha \rho \theta \dot{\alpha} \rho \eta 2001$, s. 115.

${ }^{59}$ Renfrew 1972, s. 189; Mó $\rho \theta \alpha \rho \eta$ 2001, s. 116.
} 
- szkutnictwo, żegluga i powiązany z nią handel morski, przejawiający się w imporcie, jak i eksporcie dóbr, a także idei,

- w pewnym zakresie górnictwo rud w klifach kaldery,

- pewne specjalizacje budowlane,

- wykonywanie jam grobowych, wycinanych w skale,

- produkcja wyspecjalizowanej ceramiki według mieszanych wzorów miejscowych i obcych,

- wytwarzanie narzędzi z obsydianu ${ }^{60}$.

Jednoznacznie można stwierdzić, że w interesującym nas okresie istniała już rozległa sieć kontaktów ludności wyspy Thira z innymi obszarami. Jest kwestią otwartą, na ile wymiana ta nabrała już cech czysto towarowych i może być charakteryzowana w kategoriach handlu. Jak już wyżej powiedziano, Akrotiri stało się dość znaczącym miejscem wymiany w WEB. W tym okresie mieszkańcy wyspy rozwinęli kontakty nie tylko z wyspami Morza Egejskiego. Liczne fragmenty ceramiczne (Cycladic White cykladzka biała ceramika) oraz inne przedmioty importowane wskazują, że powiązania zewnętrze w tej epoce były rozleglejsze niż wcześniej. Sięgały one aż po wybrzeża Grecji kontynentalnej [środkowohelladzka III (ŚH III) ceramika tzw. minojska], a także Krety [środkowominojska II (ŚM II) ceramika pałacowa typu Kamares] oraz zapewne po wybrzeża wysp Dodekanezu, Azji Mniejszej i Cypru ${ }^{61}$. Jednak niekoniecznie te kontakty miały charakter bezpośredni. Zapewne odbywały się w dużej mierze przez pośredników. Wymiana z wyspą Kretą miała zapewne charakter obustronny ${ }^{62}$. Godny uwagi jest fakt, że ceramika importowana została odkryta na wyspie jedynie w osadzie Akrotiri i w jej najbliższej okolicy (Potamos), co wymownie wskazuje na istnienie portu niedaleko tej osady, który odgrywał szczególną rolę w społeczno-gospodarczym życiu wyspy Thira zapewne już od początku ŚEB ${ }^{63}$.

\section{WYSPA THIRA WE WCZESNYM OKRESIE PÓŹNEJ EPOKI BRĄZU (PEB)}

\subsection{Okres późnocykladzki I (PC I) (1500-1450 p.n.e.) (ryc. 1 i tab. 1)}

Późną epokę brązu na Cykladach cechuje dominacja minojska. Niektórzy badacze nawet nazywają ją ,thalassokracją minojską". Pojęcie to zostało wprowadzone do literatury przez wielkich historyków antycznych: Tukidydesa, Herodota oraz Diodora Sycylijskiego. Oni to w swoich dziełach opisują rządy nad całym obszarem Cyklad kreteńskiego króla Minosa, rezydującego w Knossos. Władca ten miał rzekomo jako pierwszy

\footnotetext{
${ }^{60} \mathrm{M} \alpha \rho \theta \alpha \dot{\rho} \eta 2001, \mathrm{~s} .118$.

${ }^{61}$ Papagiannopoulou 1991, s. 51, 256, 264.

${ }^{62}$ Forsyth 1997, s. 37.

${ }^{63} \mathrm{M} \alpha \rho \theta \alpha \dot{\rho} \eta 2001$, s. 113.
} 
zbudować silną flotę wojenną, pozwalającą mu na panowanie na morzu, a także na wyspach, które skolonizował.

Materiał archeologiczny znajdowany w niektórych większych osadach na wyspach takich jak Filakopi na Milos, Agia Irini na Kea oraz Akrotiri na Thira, wykazuje silny stopień „minoizacji”, czyli przejmowanie pewnych cech kultury minojskiej na rodzimy grunt $^{64}$. Dobrym tego przykładem jest występowanie ceramiki lokalnej, wytwarzanej w stylu środkowocykladzkim w okresie PC I, w towarzystwie coraz częściej pojawiających się naczyń importowanych z Krety. Powstawały również liczne imitacje (naśladownictwa) kreteńskie w ceramice miejscowej.

Zjawisko „minoizacji” było obecne nie tylko w ceramice, ale również w innych dziedzinach, głównie w handlu, ponieważ w odniesieniu do okresu PC można już mówić o towarowym charakterze wymiany. Na wyspach zaczęły się pojawiać kreteńskie miary wag (odważniki) i długości, tabliczki z pismem linearnym A, jak np. tabliczka z Filakopi. Niewątpliwie wiele osad w Archipelagu Cykladzkim, ale także na wyspach Dodekanezu oraz na wybrzeżach Azji Mniejszej mogło stanowić kolonie minojskie ${ }^{65}$. Obszerniej problem kolonizacji kreteńskiej oraz termin „kolonia” porusza K. Branigan ${ }^{66}$. Jednakże jak uważa wielokrotnie cytowany badacz grecki C. Doumas, PEB na Cykladach był kontynuacją kulturową ŚEB. Pewne wpływy obce, tzn. minojskie lub helladzkie, pozostawiły swoje piętno na kulturze cykladzkiej, wszak charakter rdzennej kultury nigdy nie został znacznie zmieniony ${ }^{67}$.

W dalszym ciągu, tak jak to było wcześniej, podtrzymywano ożywione kontakty z innymi regionami Morza Egejskiego, jak Grecja kontynentalna, Azja Mniejsza, Lewant, a nawet Egipt. Kreta zapewne odgrywała dominującą rolę w handlu, a Wyspy Cykladzkie były jej pośrednikiem w kontaktach szczególnie z Grecją Kontynentalną ${ }^{68}$.

Najgęstsze zasiedlenie, jak już powiedziano, występowało od półwyspu Akrotiri do współczesnej miejscowości Emborion. Najważniejszą osadą (miastem) na wyspie było Akrotiri. Oprócz tego powstały mniejsze jednostki osadnicze w innych jej regionach, głównie jednak na półwyspie Akrotiri w południowym rejonie Thiry. Północna strefa wykazuje mniejszy stopień zasiedlenia, a to ze względu na swoje niedogodne położenie oraz mniej atrakcyjne warunki gospodarcze, niesprzyjające uprawie roli i prowadzeniu gospodarki morskiej.

W odniesieniu do okresu PC I można mówić zatem o następujących osadach: (a) w Akrotiri, (b) na wzgórzu Archangelos, (c) w Katsades, (d) niedaleko Vounari Kaparies, (e) w Balos, (f) na południe od Akrotiri, (g) na wzgórzu Mavrorachidi, (h) w Potamos (Kamara), (i) w kamieniołomie Mavromatis, (j) we Ftellos, (k) na wzgórzu Profitis Ilias, (l) w Oia, (m) w kamieniołomie Alphousos (Thirassia), (n) na wyspie Aspronisi, (o) w bliżej

\footnotetext{
${ }^{64}$ Marthari 1990, s. 65, 66; 1997, s. 362, 366, 373, 376.

${ }^{65}$ Forsyth 1997, s. 39, 40.

${ }^{66}$ Branigan 1981, s. 23-33; 1984, s. 49-53.

${ }^{67}$ Doumas 1983, s. 128.

${ }^{68}$ Forsyth 1997, s. 42.
} 
nieokreślonym miejscu na półwyspie Akrotiri, (p) w Exomiti oraz być może cmentarzysku, (q) w Sellada, a także (r) na półwyspie Koloumbos.

(a) Osada Akrotiri w omawianym okresie stanowiła rozległy kompleks założeń architektonicznych, którego dominującą cechą była gęsta, kompleksowa zabudowa poszczególnych kwartałów mieszkalnych (ryc. 16). Zauważa się nie tylko gęstą infrastrukturę, ale także wznoszenie kilkupiętrowych budynków ${ }^{69}$. Kolejną właściwością jest brak wolnych przestrzeni na zewnątrz tych konstrukcji, takich jak podwórza, dziedzińce itd. Te wszystkie wymienione cechy zabudowy rzutowały bezpośrednio na plan miasta. Cała osada składa się z następujących założeń architektonicznych: (I) Domu Zachodniego, (II) Xeste 3, (III) Xeste 2, (IV) Xeste 5, (V) Xeste 4, (VI) Domu Dam/Kobiet, (VII) Kompleksu Alfa, (VIII) Kompleksu Beta, (IX) Kompleksu Gamma, (X) Kompleksu Delta, (XI) Domu Ław, (XII) Domu Kotwicy, (XIII) Domu Pięknych Naczyń, (XIV) Domu Południowego, (XV) Budowli ST, (XVI) Budowli Z, (XVII) Budowli H, (XVIII) Budowli $\Theta$, (XIX) Budowli I, (XX) Budowli IA, (XXI) Budowli IB, (XXII) Budowli IГ, a także z Dziedzińców/Placów, (i) Dziedzińca Północnego, (ii) Placu Trójkątnego, (iii) Placu Ław, (iv) Placu Xeste 3, (v) Placu Adytonu, (vi) Placu Podwójnych Rogów, (vii) Placu Cenotafu, (viii) Placu Flotylli oraz ulic: (1) Ulicy Telchinów, (2) Ulicy Kurytów, (3) Ulicy Demonów oraz (4) Ulicy Daktylów. W toku eksploracji tych założeń pozyskano bardzo dużą ilość materiału ruchomego wszelkiego rodzaju, zwłaszcza ceramiki naczyniowej (ryc. 17, 18, 19).

(I) Dom Zachodni (DZ) stanowi kompleks, który został najlepiej zbadany ze wszystkich założeń architektonicznych odsłoniętych na stanowisku. Znajduje się on w północno-zachodniej części miasta, na północny zachód od Domu Kotwicy (opisanego poniżej) oraz naprzeciwko Pylonu w Kompleksie Delta. Od północy jego południową ścianę zamyka Plac Trójkątny, do którego dochodziła Droga Telchinów. Ten skwer uzyskał przybliżoną formę trójkąta, ponieważ znajdujący się przy nim DZ został wzniesiony w całkowicie odmiennej orientacji w stosunku do innych budowli znajdujących się na stanowisku.

$\mathrm{Z}$ rozplanowania wynika także, że DZ stanowił podłużny, wolno stojący budynek średniej wielkości (południowa ściana frontowa od Drogi Telchinów ma około $15 \mathrm{~m}$ długości i w niej znajdują się drzwi wejściowe z niewielkim otworem okiennym $(1,15 \times 0,64 \mathrm{~m})$ przy nich. Wspomniana fasada południowa ma na poziomie sutereny cztery otwory okienne o różnych wielkościach. Na piętrze usytuowane są w niej trzy rozległe okna ${ }^{70}$. Odbudowany po zniszczeniach spowodowanych trzęsieniem ziemi poprzedzającym wielką erupcję w PEB, DZ w swej ostatecznej formie posiadał parter, pierwsze piętro, a w części wschodniej być może nawet drugie piętro.

Wejście do DZ umieszczone było w północnej części ściany południowej, która jak już wspomniano - przylega do Trójkątnego Placu. Wchodząc do budynku, trafiało się

\footnotetext{
${ }^{69}$ Doumas 1974, s. 199.

${ }^{70}$ Marinatos 1972, s. 18, tabl. 22, 23, 24a i b.
} 

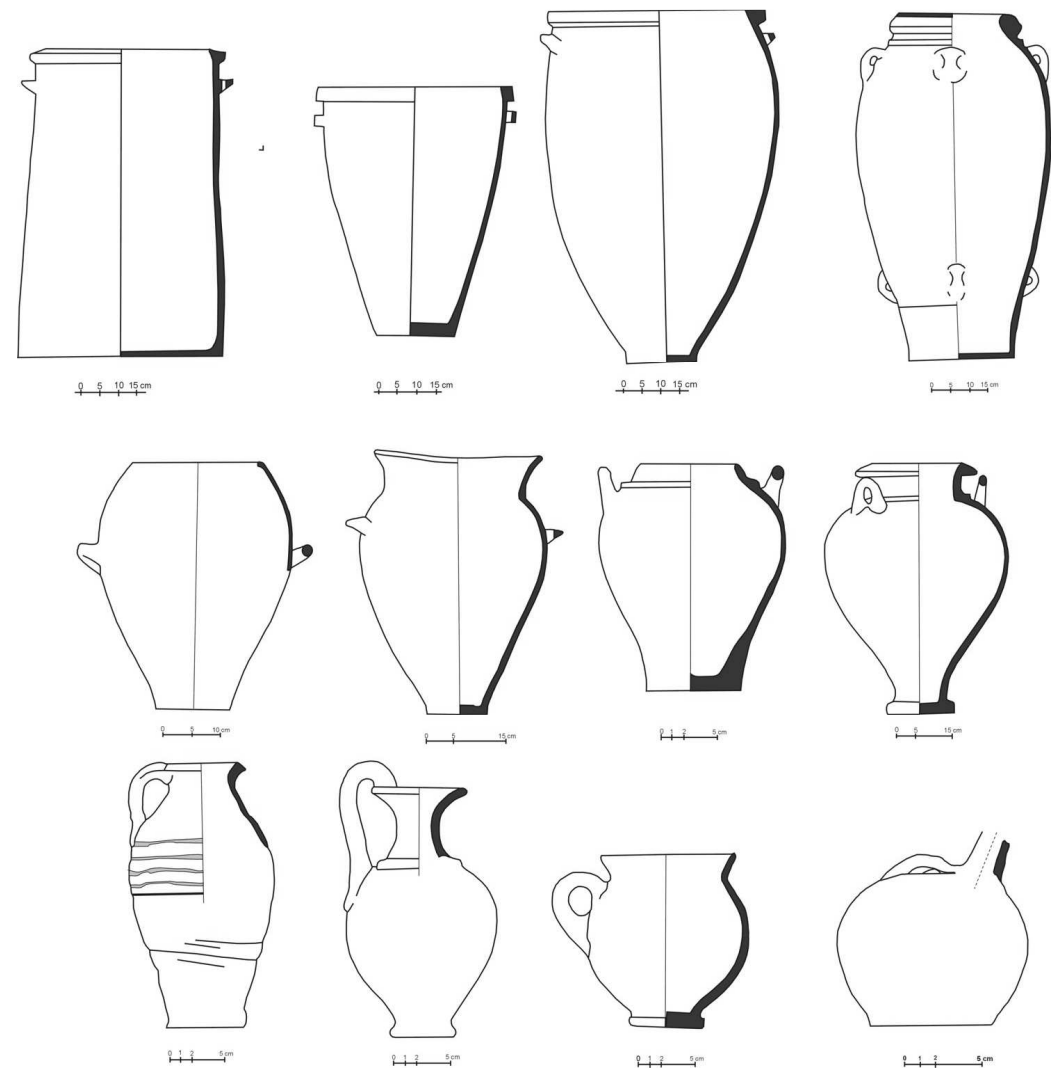

Ryc. 17. Akrotiri. Formy ceramiczne z PEB (wg Doumas 1983)

Fig. 17. Akrotiri. Late Bronze Age ceramic forms (Doumas 1983)

do pomieszczeń 1 i 2, które służyły jako swego rodzaju przedpokoje. W nich także znajdowały się schody główne, umożliwiające komunikację z wszystkimi piętrami. Ponadto istniała jeszcze jedna klatka schodowa, określana jako pomocnicza, położona w północnym skrzydle DZ. Łączyła ona tylko parter z pierwszym piętrem.

$\mathrm{Na}$ poziomie parteru, sądząc po znaleziskach, znajdowały się pomieszczenia pomocnicze i gospodarcze, takie jak: magazyny na naczynia do przechowywania żywności, instalacje do jej produkcji, warsztaty oraz inne założenia ${ }^{71}$. Piętra tworzyły właściwą przestrzeń mieszkalną, a w niektórych przypadkach nawet kultową. Z DZ pochodzą również słynne malowidła ścienne przedstawiające „Rybaków”, „Kapłankę” oraz „Miniaturowy Fryz", który składa się z kilku epizodów przedstawiających różne sceny z życia codziennego, „Wrak Statku”, „Wojownicy”, „Zgromadzenie na Wzgórzu”, „Kra-

${ }^{71}$ Marinatos 1974, s. 19-24. 
jobraz nad Nilem” oraz „Procesja Statków” (pomieszczenie 5 tego założenia), a także „Kabiny rufowe” (pomieszczenia 4a i 4b).

(II) Kompleks pomieszczeń znany jako Xeste 3 zajmuje południowo-zachodnią część stanowiska. Zbudowany został z bloków kamiennych, pochodzących z tego samego kamieniołomu, a całość konstrukcji została wzmocniona ponadto drewnem. Ściana fasady mierzy około $12 \mathrm{~m}$ długości. Przyjmuje się, że Xeste 3 mogło mieć pierwotnie dwa lub trzy piętra. Na poziomie parteru Xeste 3 ma 15 pomieszczeń różnej wielkości ${ }^{72}$. Cała budowla dzieli się na dwie zasadnicze części: wschodnią i zachodnią. Pierwszej czę-
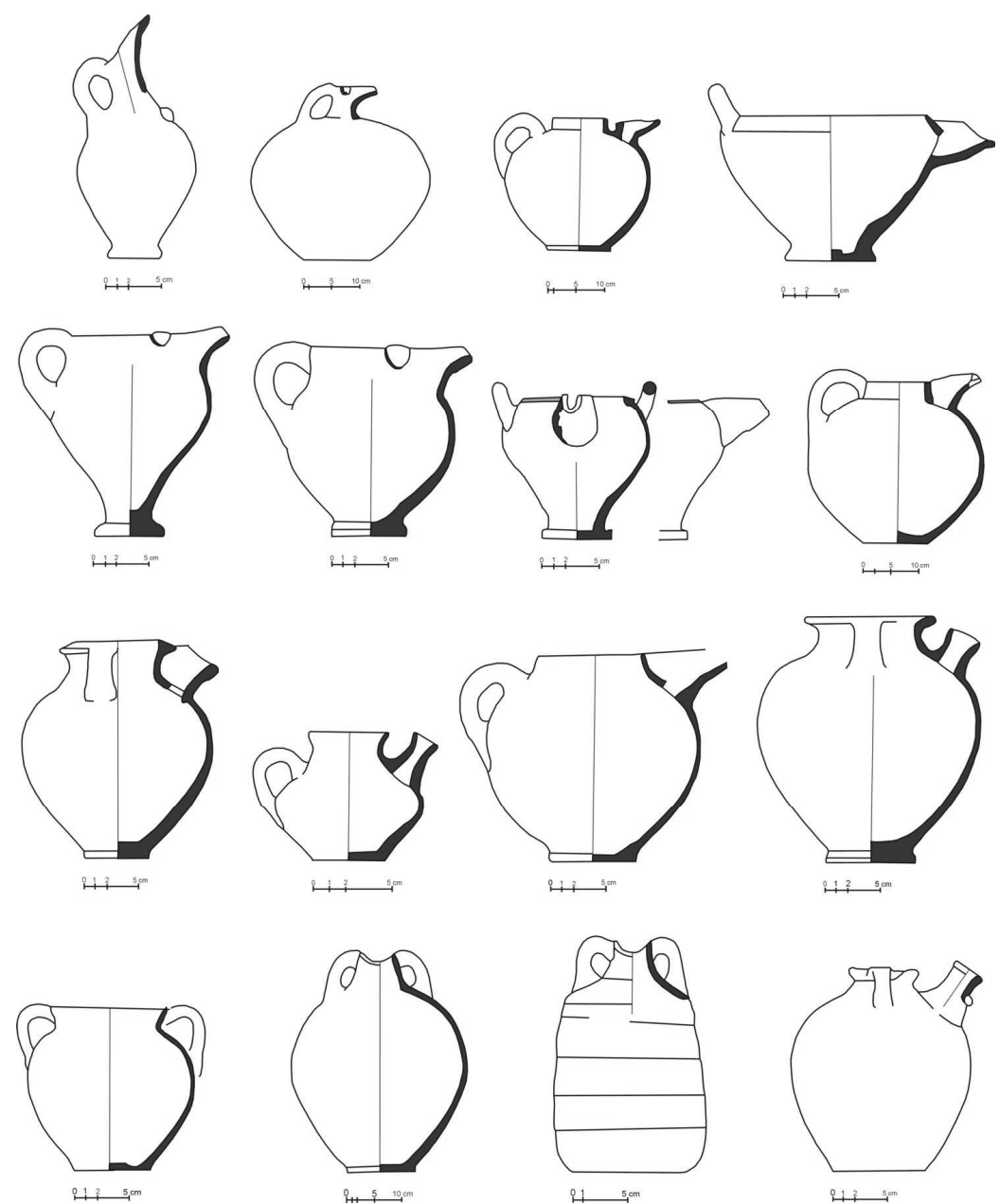

Ryc.18. Akrotiri. Formy ceramiczne PEB (wg Doumas 1983)

Fig. 18. Akrotiri. Late Bronze Age ceramic forms cont. (D o u mas 1983)

\footnotetext{
${ }^{72}$ Marinatos 1974, s. $15-17$.
} 

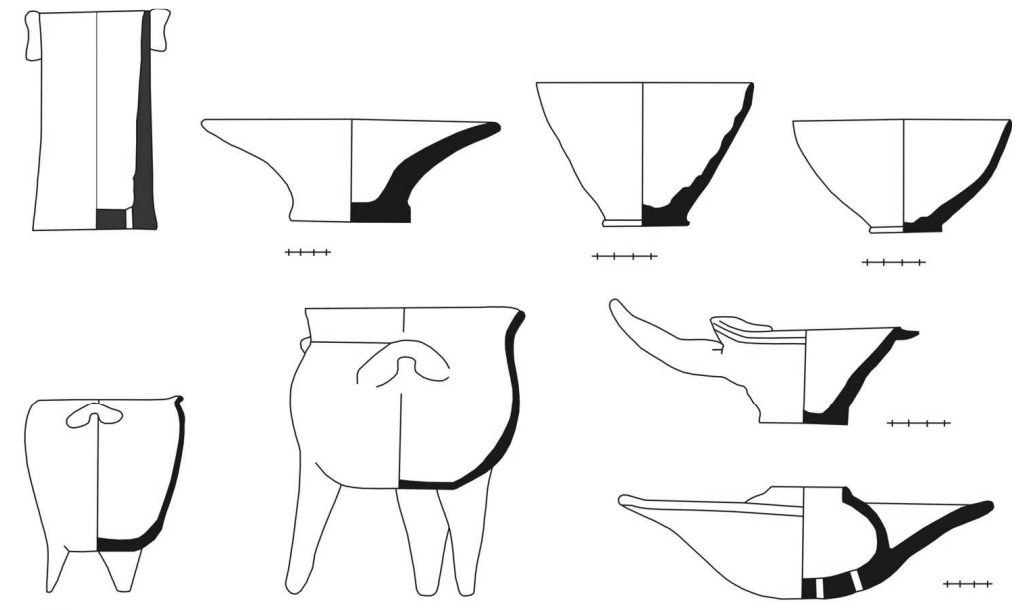

ili spm
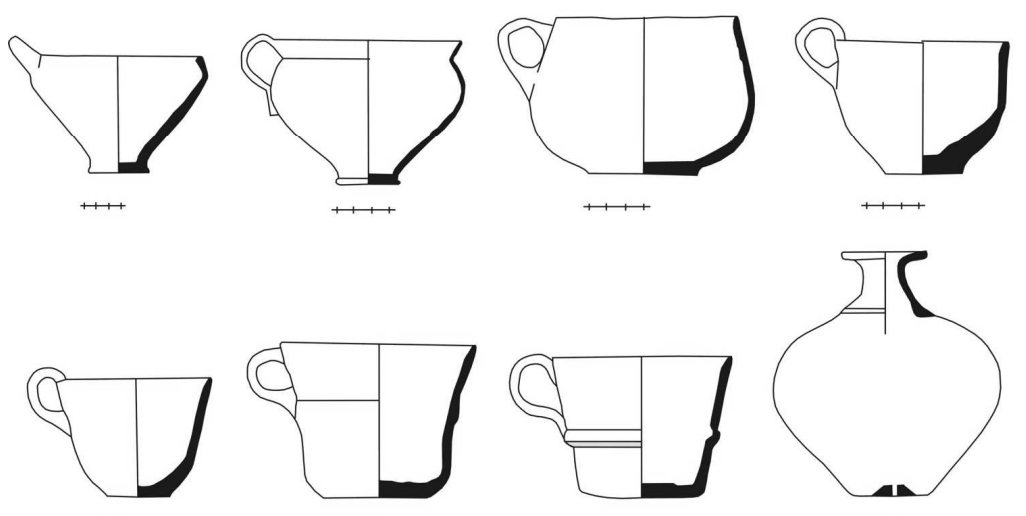

Ryc. 19. Akrotiri. Formy ceramiczne PEB (wg Doumas 1983)

Fig. 19. Akrotiri. Late Bronze Age ceramic forms cont. (Doumas 1983)

ści przypisywano początkowo rolę przestrzeni sakralnej bądź ceremonialnej, ze względu na obszerne pomieszczenia - polithira (element architektoniczny złożony z wielu drzwi), malowidła ścienne oraz na adyton (miejsce, do którego miały dostęp tylko osoby bezpo-

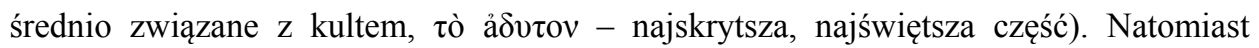
zachodnia część, sądząc po niewielkich rozmiarach, braku tzw. polithira oraz niezbyt zaawansowanym poziomie wykonania malowideł ściennych, znajdujących się tylko $\mathrm{w}$ jednym niewielkim pomieszczeniu, służyła zapewne jako szereg pomieszczeń magazynowych lub pomocniczych. W tym założeniu odkryto również freski ścienne: „Krajobraz Egzotyczny”, „Adoratorki”, „Nadzy Młodzieńcy” oraz „Kobiety Zbierające Krokusy”.

(III) Interesujący nas obiekt (Xeste 2) znajduje się dokładnie na południowy wschód od Xeste 5 i stanowi południowe ograniczenie wymienionego wyżej placu, który od 
zachodu jest zamykany przez Kompleks Delta (KD). Pierwsze ślady jego egzystencji zostały uchwycone podczas wykonywania sondażu w1967 r., kiedy to natrafiono na jego północno-zachodni narożnik. Powszechnie przyjmuje się za S. Marinatosem, że chodzi tu o największą strukturę w całym mieście i jednocześnie najbardziej monumentalną. O takim jej charakterze może świadczyć odsłonięta dotychczas na około $20 \mathrm{~m}$ długości zachodnia fasada oraz na $12 \mathrm{~m}$ na wschód północna fasada, która jednakże jeszcze nie została odkryta do końca. Na całej jej długości występują liczne otwory okienne, a także różnej wielkości nisze. Przy fasadzie zachodniej dają się zauważyć dwie niewielkie dobudówki oznaczone I (północna, na planie w przybliżeniu kwadratu) oraz II (południowa, na planie prostokąta). Jej wnętrze nie zostało jeszcze zbadane. Pewnego, bardzo skromnego obrazu wewnętrznej zabudowy dostarczają dane otrzymane podczas wykonywania szybów pod słupy podtrzymujące zadaszenie, zakładane nad całą powierzchnią stanowiska $^{73}$.

(IV) Bardzo niewiele można powiedzieć o Xeste 5. Położone jest na wschód od KD i na północ od podobnej do niego struktury zwanej Xeste 2. Dotychczas udało się zbadać stosunkowo dobrze jedynie fragmenty ścian zachodniej i południowej. Wydaje się, że było to założenie o dużych rozmiarach, na co wskazują monumentalne ściany, których zewnętrzne partie zostały wzniesione z regularnych bloków skalnych. Ta budowla tworzy północną granicę niewielkiego, wspomnianego już placu.

Wewnętrzne rozplanowanie budowli jest prawie niemożliwe. Jedyny odnośny materiał pozyskano podczas wykonywania szybów pod podstawy filarów podtrzymujących dach. Materiał ten datowany jest jednak na wcześniejsze fazy zasiedlenia owego miasta.

(V) Uchodzi za jedno z najbardziej monumentalnych i złożonych pod względem architektonicznym, niezależnych założeń, odsłoniętych dotychczas na stanowisku Akrotiri, ustępując miejsca jedynie Xeste 2. Jego wszystkie ściany obwodowe wzniesione zostały

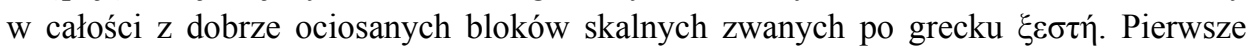
wskazówki jego położenia zostały uchwycone podczas wykonywania szybu \# 41 pod filar podtrzymujący zadaszenie nad stanowiskiem, w $1972 \mathrm{r}^{74}$ Wydaje się, że ten obiekt miał dwa piętra. Na całej powierzchni (na dł. ponad $25 \mathrm{~m}$ ) północnej ściany nie ma żadnego otworu, natomiast ściana południowa jest rozczłonkowana licznymi niszami i wypustami. Główne wejście do całego kompleksu znajduje się w zachodniej części. Prace badawcze tego założenia są nadal w toku, dlatego nie można zbyt wiele powiedzieć o rozplanowaniu przestrzennym. Dotychczas odsłonięto tylko niektóre elementy tej imponującej struktury (ściany zewnętrzne, polithira oraz kilka pomieszczeń zlokalizowanych na piętrze). Z tej budowli pochodzi znany fresk „Procesja”.

(VI) Dom Dam (DD) położony jest w północnej części miasta Akrotiri, na północ od DZ i KD. Nazwę swą zawdzięcza odkrytym tam malowidłom ściennym, przedstawiającym kobiety. Po raz pierwszy nazwa ta została użyta przez S. Marinatosa w sezonie

\footnotetext{
${ }^{73}$ Marinatos 1974 , s. $13,14$.

${ }^{74}$ Marinatos 1972 , s. 15.
} 
wykopaliskowym $1971^{75}$. Z danych architektonicznych i archeologicznych, które uzyskano w toku eksploracji tego obiektu, wynika, że chodzi prawdopodobnie o trzypiętrowy kompleks (wraz z parterem). Nie ma jednak pewności co do tego, czy liczył on trzy piętra na całej swej długości, natomiast wiadomo, że zachodnia część budowli była trzypiętrowa, na co wskazują zachowane pomimo erozji (działalność okresowego cieku wodnego) fragmenty ścian ${ }^{76}$.

Wyposażona była ponadto $\mathrm{w}$ dwie klatki schodowe umożliwiające komunikację pomiędzy kolejnymi piętrami: główną, zlokalizowaną naprzeciw wejścia w południowo-zachodnim narożniku tego budynku, oraz pomocniczą, która znajdowała się prawie w samym centrum budowli. Analizowany budynek charakteryzuje się także cechą architektoniczną, która jest porównywalna jedynie z budowlami pałacowymi na Krecie wolną przestrzenią, swego rodzaju dziedzińcem, umożliwiającym dostęp światła słonecznego do poszczególnych pomieszczeń DD. Na każdym piętrze było przynajmniej dziesięć pomieszczeń różnej wielkości. Cała budowla pełniła zapewne rolę bogatej prywatnej rezydencji, chociaż niektórzy badacze doszukują się w niej obiektu kultoworeligijnego ze względu na wspaniale zachowane freski („Fresk Kobiet”, „Fresk Lilii”).

(VII) Kompleks Alfa to założenie architektoniczne, które zostało najwcześniej odsłonięte na stanowisku Akrotiri, tzn. podczas sezonów wykopaliskowych 1967-1968. W początkowej fazie wykopalisk obszar, na którym się ono znajduje, zwano Arvaniti I, od nazwiska właściciela gruntu. Kompleks składa się z trzech Pomieszczeń Magazynowych, położonych na poziomie piwnicy. Do tego zespołu zalicza się także założenia oddzielone tzw. Podwójnym Murem, a które umownie nazywa się Pomieszczeniami lub Apartamentami Zachodnimi, ze względu na ich położenie w stosunku do Pomieszczeń Magazynowych. Apartamenty Zachodnie, oprócz Młyna, znajdowały się raczej na wyższym piętrze i były to także trzy pomieszczenia. Od południa natomiast KA graniczy z wąskim przejściem lub uliczką biegnącym(ą) z zachodu na wschód, które(ą) zwie się Korytarzem Południowym. Po lewej stronie tego Korytarza, w jego zachodniej części, usytuowane jest niewielkie pomieszczenie nazwane przez S. N. Marinatosa Domkiem lub Stróżówką Portiera. Oprócz tego zalicza się do KA niewielki fragment brukowanej drogi, który jest zapewne przedłużeniem Drogi Telchinów ${ }^{77}$.

(VIII) Kompleks Beta (KB) usytuowany jest przy wschodniej stronie Drogi Telchinów. Od północy sąsiaduje $\mathrm{z} \mathrm{KD}$, natomiast od zachodu oddziela go od innego zespołu architektonicznego (zwanego KG) rzeczona Droga Telchinów ${ }^{78}$. Stosunkowo łatwo daje się zauważyć, że KB tworzą dwa różne zespoły pomieszczeń. Na pierwszy zespół składają się pomieszczenia 1-4 oraz 6-7, drugi zaś to zupełnie inna jednostka architektoniczna, którą tworzą pomieszczenia 5, 5a i 8 . Zdaniem architekta greckiego C. Palyvou

\footnotetext{
${ }^{75}$ Marinatos 1972, s. 11; Forsyth 1997, s. 81-84; Doumas 1992.

${ }^{76} \mathrm{~N} \tau$ ov́ $\mu \alpha_{\varsigma}$ 1992c; Forsyth 1997, s. 81.

${ }^{77}$ Marinatos 1968; 1969.

${ }^{78}$ Forsyth 1997, s. 61.
} 
zespół ten został dobudowany w późniejszym okresie, aby wypełnić lukę powstałą pomiędzy dwoma wielkimi założeniami, jakimi są $\mathrm{KB}$ i $\mathrm{KD}^{79}$. Wydaje się także, że rdzeniem KB były pomieszczenia $1-4$ i $6-7$. Dokładne rozplanowanie przestrzenne tego kompleksu nie jest do końca rozpoznane, ponieważ płynący okresowo potok (destrukcja założenia w jego południowej części) spowodował zniszczenia. Z tej samej przyczyny niemożliwe jest również zlokalizowanie otworu wejściowego tej jednostki architektonicznej. Istnieją przypuszczenia, że istniał on we wschodniej lub południowej fasadzie ${ }^{80}$.

Na podstawie danych architektonicznych i archeologicznych, uzyskanych do tej pory, sądzi się, że KB był dwupiętrową „rezydencją”. W budowli znajdują się również słynne freski: „Walczące na Pięści Dzieci”, „Antylopy” oraz „Niebieskie Małpy”.

(IX) Kompleks Gamma (KG) położony jest na północny wschód od Xeste 3. Od strony wschodniej przylega do Drogi Telchinów, która oddziela go od KB. Podczas trzęsienia ziemi, zaistniałego przed definitywnym wybuchem wulkanu thirańskiego, założenie to uległo rozległym zniszczeniom, do dzisiaj czytelnym w materiale archeologicznym.

Zasadniczo KG składa się również z dwóch kompleksów pomieszczeń - południowego i północnego. Południowa część obejmuje jednostki G1, G2, G2a oraz G3, z bardzo grubymi ścianami (do 1,50 m). Taką grubość ma przynajmniej zachodnia ściana, którą dodatkowo wzmocniono drewnianymi belkami ${ }^{81}$. Na podstawie niezwykłej monumentalności tych ścian przypuszcza się, że chociażby południowa część KG musiała mieć przynajmniej jedno piętro. S. Marinatos określił założenie jako kompleks warsztatów ${ }^{82}$.

KG dostarcza także danych odnośnie do odbudowy miasta po zniszczeniach dokonanych przez trzęsienia ziemi. Widoczna jest przy tym działalność tzw. squatters, czyli osób (najprawdopodobniej mieszkańców Akrotiri, którzy powrócili po kataklizmie w celu uprzątnięcia zniszczeń i odbudowy miasta). Ich praca przejawiła się w omawianym kompleksie wzniesieniem prowizorycznych ścian, wspierających naruszone podczas katastrofy mury oraz oczyszczaniem z gruzów. Te tymczasowe ściany wznoszono zazwyczaj z bloków kamiennych, pozyskanych z oczyszczania wnętrz budynków i ulic miasta, bez zaprawy glinianej jako spoiwa ${ }^{83}$.

(X) Kompleks Delta (KD) położony jest na północ od opisanego wyżej KB i swoją fasadą dotyka Drogi Telchinów. Tworzą go co najmniej cztery jednostki architektoniczne. Powstał on w wyniku dobudowy kolejnych pomieszczeń do wewnętrznej konstrukcji, która istniała wcześniej ${ }^{84}$. Na poziomie parteru poszczególne pomieszczenia two rzyły niezależne struktury, jednak istnieje duże prawdopodobieństwo, że na górnych piętrach występowały zgrupowania lokali tworzące odrębne mieszkania. Założenie to

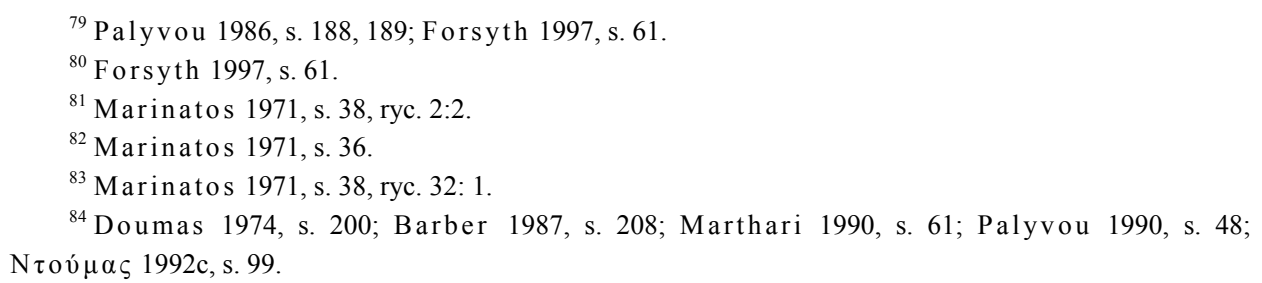


mogło mieć jeszcze bardziej złożony charakter. Jego wygląd został w dużej mierze zmieniony po rozbudowie miasta zrealizowanej po zniszczeniach spowodowanych trzęsieniami ziemi we wczesnym okresie PC. Wydaje się nawet, że pewna część KD została później celowo zburzona i zniwelowana pod budowę publicznych placów bądź podwórzy. Tego typu zabiegi są widoczne na południe od pomieszczenia D15, na wschód od pomieszczeń D9, D10, D11 i D12 oraz na północ od pomieszczenia D $3^{85} . \mathrm{Z}$ omawianego założenia pochodzi „Fresk Wiosenny”.

(XI) Dom Ław (OIKIA $\Theta P A N I \Omega N$ ) bierze nazwę od murowanych lawek odkrytych w północno-wschodnim narożniku tego domu. Znajdowały one się po obu stronach domniemanego wejścia, znajdującego się we wschodniej ścianie. Pozostałości DŁ zlokalizowano na północny zachód od Xeste 3. Odkryta partia była w dużej mierze zniszczona przez okresowy potok ${ }^{86}$.

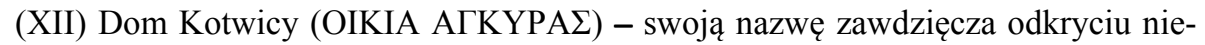
wielkiego fragmentu skały - trachitu, który badacze zidentyfikowali na podstawie kształtu oraz otworu w górnej swej części jako fragment kotwicy. Cały przedmiot waży około $65 \mathrm{~kg}$ i mierzy około $60 \mathrm{~cm}$ długości. DK jest usytuowany po zachodniej stronie Trójkątnego Placu, dokładnie naprzeciw Pylonu, należącego do KD oraz w sąsiedztwie DZ. Wejście do niego znajdowało się zapewne w północnym narożniku. W tym samym narożniku znajdowało się duże okno. Podczas eksploracji tego założenia zarejestrowano niewiele fragmentów ceramicznych, wśród których znalazł się jeden „import” kreteński typu Kamares ${ }^{87}$.

(XIII) Dom Pięknych Naczyń (OIKIA T $\Omega$ N KA $\Lambda \Omega N$ АГГЕI $\Omega N$ ) - niewielkie relikty architektoniczne tego obiektu odsłonięto na północ od Xeste 4. Nazwę swą zawdzięcza znalezisku kilku pięknych naczyń.

(XIV) Dom Południowy (NOTIO KTIIMA) - usytuowany jest na południe od Xeste 4, stąd też bierze się jego nazwa.

(XV) Budowla ST (KTIPIO $\Sigma$ T) - pewne jego relikty zostały zlokalizowane na północ od Xeste 3.

(XVI) Budowla Z (KTIPIO Z) - niewielki fragment zarysu zewnętrznego, należący do tej budowli został odsłonięty na północ od Domu Zachodniego.

(XVII) Budowla H (KTIPIO H) - jej pozostałości zlokalizowano na południe od Budowli A i na wschód od Domu Kobiet.

(XVIII) Budowla $\Theta$ (KTIPIO $\Theta$ ) - początkowo uważano, że jest to południowa część Domu Kobiet. W toku prac wykopaliskowych ujawniono jej niezależny charakter.

(XIX) Budowla I (KTIPIO I) - zlokalizowana jest na wschód od Budowli B. Jej zachodnie skrzydło zostało prawie doszczętnie zniszczone przez działalność okresowo płynącego przez stanowisko potoku. S. N. Marinatos przypisał ją jako część Xeste $2^{88}$.

\footnotetext{
${ }^{85}$ Palyvou 1984, s. 119-147; 1986, s. 194; Forsyth 1997, s. 66.

${ }^{86} \mathrm{~N} \tau$ ov́ $\mu \alpha \varsigma$ 1990, s. 234.

${ }^{87}$ Marinatos 1974, s. 18, 19.

${ }^{88}$ Marinatos 1974, s. 11.
} 
(XX) Budowla IA (KTIPIO IA) - niewielki fragment jej zarysu został zarejestrowany na północ od Xeste 4.

(XXI) Budowla IB (KTIPIO IB) - w toku prac wykopaliskowych ostatecznie udało się odsłonić jej północną fasadę, a zlokalizowana jest na południe od Xeste 4.

(XXII) Budowla IГ (KTIPIO ІГ) - znane są tylko niewielkie relikty jej muru na północ od Budowli $\Gamma$.

(i) Dziedziniec Północny (Dziedziniec Młyński) (BOPEIA AY $\Lambda \mathrm{H}, \Pi \Lambda A T E I A$ MY $\Lambda \Omega N O \Sigma)$ - plac ten znajduje się przy wejściu do Młyna w pomieszczeniu D15 Kompleksu Delta.

(ii) Plac Trójkątny (П $\Lambda$ ATEIA ТРIГ $\Omega N O Y$ ) - ma w przybliżeniu trójkątny kształt i usytuowany jest przed Domem Zachodnim ${ }^{89}$.

(iii) Plac Ław (П $\Lambda$ ATEIA $\Theta P A N I \Omega N$ ) - jest to wolna przestrzeń rozciągająca się na wschód przed domem noszącym tę samą nazwę.

(iv) Plac Xeste 3 (П $\Lambda$ ATEIA $\Xi E \Sigma T H \Sigma$ 3) - zajmuje on obszar na wschód od Xeste 3.

(v) Plac Adytonu (П $\Lambda$ ATEIA $\triangle \mathrm{E} \Xi A M E N H \Sigma \mathrm{KA \Theta APM \Omega N}$ ) - taką nazwę nosi przestrzeń położona na zachód od Budowli $\Gamma$, zawdzięczającą założeniu adytonu $\mathrm{w}$ jednym z pomieszczeń Xeste 3.

(vi) Plac Podwójnych Rogów (П $\Lambda$ ATEIA $\triangle \mathrm{I} \Pi \Lambda \Omega$ N KEPAT $\Omega N$ ) - to wolna przestrzeń, która od zachodu ograniczona jest przez Kompleks D, od północy przez Xeste 5a, od południa przez Xeste 2. Nazwę swą zawdzięcza znalezisku dwóch rogów przed pomieszczeniem D8.

(vii) Plac Cenotafu (П АТTEIA KENOTAФIOY) - zlokalizowany jest na północ od Kompleksu D. Jego nazwa natomiast wzięła się od znaleziska bezpochówkowego grobu.

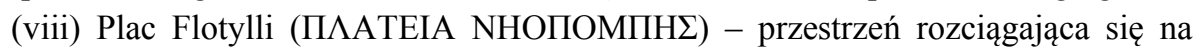
północny zachód od Domu Zachodniego. Otrzymał taką nazwę, ponieważ z niego można było zapewne dostrzec fryz flotylli, zdobiący południową ścianę pomieszczenia 5 w Domu Zachodnim.

(1) Ulica Telchinów $(\mathrm{O} \Delta \mathrm{O} \Sigma \mathrm{TE} \Lambda \mathrm{XIN} \Omega \mathrm{N})$ - nazwę jej wprowadził po raz pierwszy S. N. Marinatos na określenie drogi biegnącej przez prawie całe dotychczas odsłonięte stanowisko.

(2) Ulica Kurytów $(\mathrm{O} \Delta \mathrm{O} \Sigma$ KOYPHT $\Omega \mathrm{N})$ znajduje się pomiędzy Xeste 4 a Budowlą IB.

(3) Ulica Demonów $(\mathrm{O} \Delta \mathrm{O} \Sigma \Delta \mathrm{AIMON} \Omega \mathrm{N})$ biegnie przy Xeste 5.

(4) Ulica Daktylów $(\mathrm{O} \Delta \mathrm{O} \Sigma \Delta \mathrm{AKTY} \Lambda \Omega \mathrm{N})$ - pomiędzy Domem Kobiet a Budowlą $\mathrm{H}$.

(b) Na wzgórzu Archangelos C. Doumas zarejestrował podczas badań powierzchniowych liczne fragmenty ceramiczne, zalegające na szczycie tego wzniesienia, które datowane są na okres PC. Jest to zatem kolejny dowód na długotrwałe wykorzystywanie tej osady ${ }^{90}$.

\footnotetext{
${ }^{89}$ Marinatos 1974, s. $18,19$.

${ }^{90}$ Doumas 1983, s. 27.
} 
(c) Bardziej na północ od wyżej wymienionego położone jest stanowisko Katsades, na którym odkryto fragmenty malowanych naczyń zasobowych z okresu PC. W pobliżu tego miejsca również francuscy badacze w 1870 r. założyli sondaże próbne, w których natknęli się na mury i ceramikę datowaną na okres PC I. Powszechnie uważa się, że $\mathrm{w}$ tym miejscu istniała $\mathrm{w}$ interesującym nas okresie niewielka wioska o rozproszonej zabudowie $^{91}$.

d) Inne pozostałości ceramiczno-architektoniczne z okresu PC I zostały zarejestrowane in situ podczas budowy drogi prowadzącej do miejscowości Vounari Kaparies ${ }^{92}$.

(e) Kolejnym stanowiskiem jest osada w Balos, położona na krawędzi kaldery. Została ona zbadana przez H. Mameta i H. Gorceixa w 1870 r. ${ }^{93}$ Tutaj pokład pumeksu został znacznie zredukowany przez jego eksplorację do celów budowlanych, co ułatwiło dostęp do warstw kulturowych.

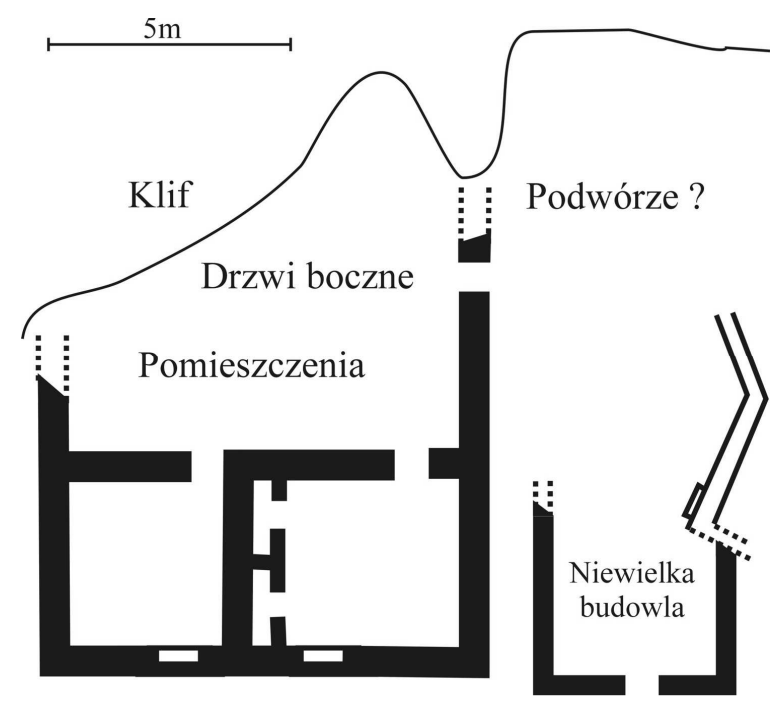

Ryc. 20. Balos (wg Fouque 1879 za F ors y th 1997 z modyfikacjami) Fig. 20. Balos (F ou que 1879 acc. to Fors yth 1997 with modifications)

Zarejestrowano tam dwa założenia (ryc. 20). Zostały one zbudowane na skraju kaldery. Jedno z nich nosi ślady zniszczeń spowodowanych wybuchem wulkanu thirańskiego, ponieważ jego część zapadła się wraz z kalderą ${ }^{94}$. Na podstawie obserwacji wiemy,

${ }^{91}$ Fouqué 1879, s. 122; Barber 1981, s. 20; Davis, Cherry 1990, s. 190.

${ }^{92}$ Forsyth 1997 , s. 45.

${ }^{93}$ Mamet, Gorceix 1870, s. 183-203; Mamet 1874, s. 27-30; Fouquè 1879, s. 118-123; Sperling 1973.

${ }^{94}$ Mamet, Gorceix 1870, s. 183-203; Mamet 1874, s. 27-30. 
że były to budowle wolno stojące, które dzielił jedynie niewielki korytarz. Największa $\mathrm{z}$ nich mierzyła około $9,7 \times 9,4 \mathrm{~m}$ i została skonstruowana $\mathrm{z}$ drewna i ciosanych kamieni. Jej ściany nosiły ślady tynkowania, natomiast wewnętrzna ich strona pokryta była zapewne żółtą farbą, na co wskazywałyby pozostałości substancji znalezionej podczas wykopalisk. Omawiany dom składał się z przynajmniej czterech pomieszczeń (zapewne było ich więcej, ale wspomniane wyżej nie pozwalają na jednoznaczne ich potwierdzenie). Dwa z nich były położone na północy i dwa na południu założenia. Północne były rozmiarowo większe od południowych. W analizowanych pomieszczeniach znaleziono liczne zabytki ruchome. Pomieszczenie południowo-wschodnie zawierało dodatkowo dwa wąskie, niewielkie pokoje. We wnętrzu wschodnim zarejestrowano na podłodze kości kóz i owiec, nakryte słomą. Funkcja tego pomieszczenia jest niejasna; być może była to stajnia ${ }^{95}$.

Podczas eksploracji pomieszczeń odkryto znaczną liczbę naczyń zasobowych; niektóre z nich zawierały jeszcze niewielkie ilości ziaren jęczmienia, grochu i soczewicy. Ponadto zarejestrowano wyroby $\mathrm{z}$ obsydianu. $\mathrm{Z}$ gotowych narzędzi znana jest tylko miedziana piła. $Z$ analiz ceramiki wynika, że budowla ta funkcjonowała w okresie PC I. Przyjmuje się, że były to pomieszczenia gospodarcze związane ze zwierzętami domowymi. Znaleziska naczyń z ziarnem, które mogło stanowić paszę dla zwierząt, brak okien, pozostałości słomy na podłodze oraz szkielet zwierzęcy jednoznacznie wskazują na ich gospodarczą funkcję ${ }^{96}$. Grecki archeolog C. Doumas spekuluje, że te oraz inne budowle na omawianym stanowisku stanowić mogły suburbium miasta Akrotiri, a to ze względu na niewielką odległość, jaka dzieliła je od centrum tego osiedla.

(f) Kolejnym miejscem zbadanym archeologicznie przez H. Gorceixa i H. Mameta był wąwóz położony na południe od Akrotiri. Dokładna jego lokalizacja jest nieznana. Podczas zakładania wykopów sondażowych natknęli się oni na fragmenty murów i ceramikę, którą na podstawie zdobnictwa wydatowano na okres PC. W toku dalszej eksploracji odsłonili oni założenie posadowione bezpośrednio na skale (ryc. 21, 22). Jego ściany miały grubość $50 \mathrm{~cm}$ i zachowały się w niektórych miejscach do wysokości $2 \mathrm{~m}$. Kamienie, które posłużyły do wzniesienia tego budynku były tylko zgrubnie doprowadzone do regularnych kształtów i połączone glinianą zaprawą. Jednymi z ciekawszych pomieszczeń są pokoje $\mathrm{E}$ i F, ponieważ ich ściany były od wewnątrz pokryte tynkiem, na którym zachowały się fragmenty różnorodnych malowideł. Z zabytków ruchomych należy wymienić piłę, noże, skrobacze z obsydianu, ponadto moździerze, żarna, ciężarki tkackie oraz wiele naczyń zachowanych prawie w całości. Oprócz tego zarejestrowano także wiele kości zwierzęcych, głównie owcy i kozy ${ }^{97}$.

(g) Na południe od Balos znajduje się niewielkie wzniesienie Mavrorachidi, gdzie C. Doumas odkrył fragmenty murów, wiele naczyń ceramicznych i marmurowych oraz frag-

\footnotetext{
${ }^{95}$ Forsyth 1997, s. 46.

${ }^{96}$ Forsyth 1997, s. 46.

${ }^{97}$ Page 1970, s. 26, 28.
} 


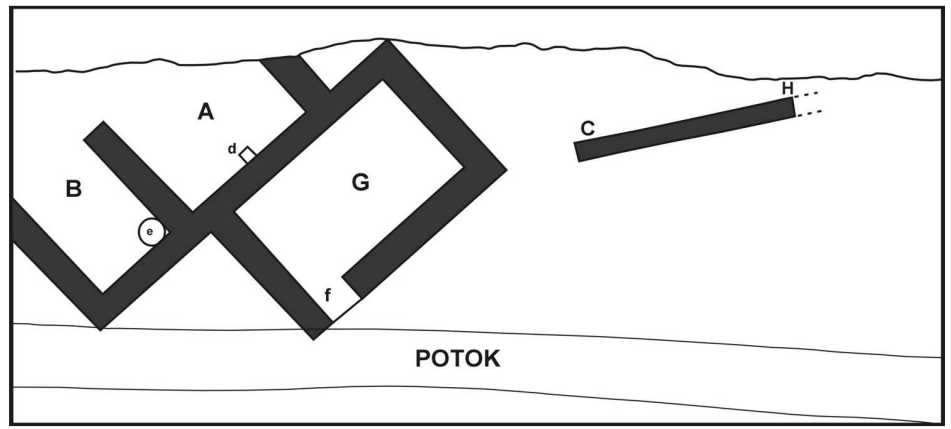

Ryc. 21. Wąwóz na południe od Akrotiri (wg Page 1970)

Fig. 21. A ravine south of Akrotiri (Page 1970)

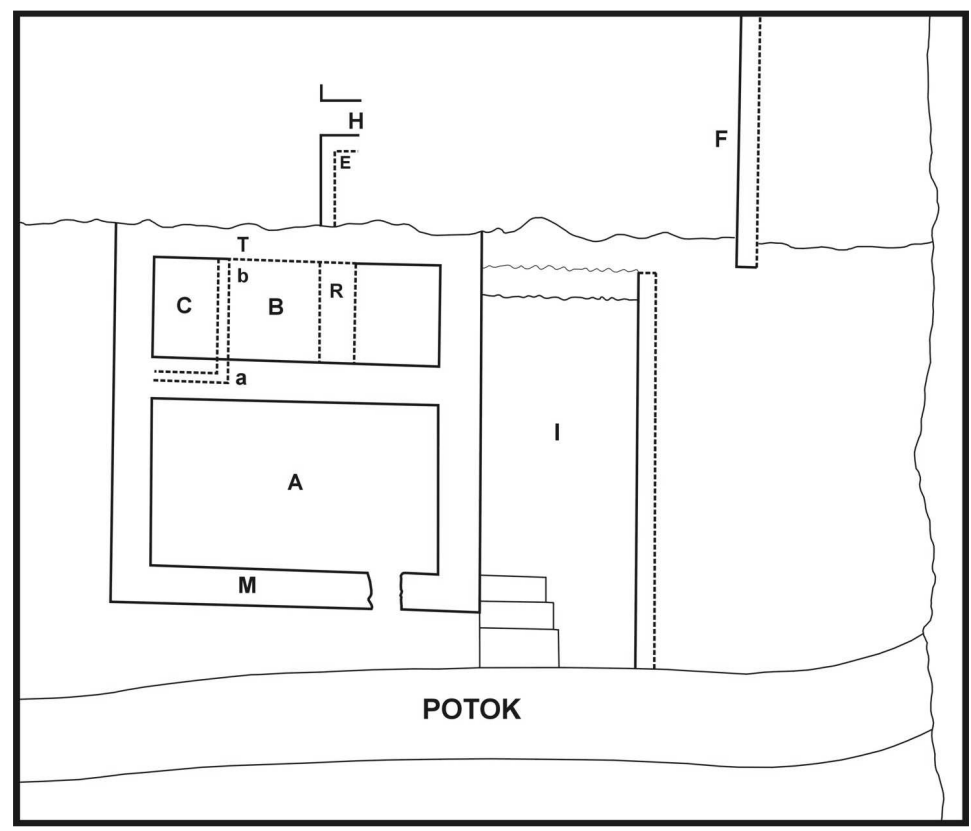

Ryc. 22. Wąwóz na południe od Akrotiri (wg Page 1970, s. 27, fig. 16)

Fig. 22. A ravine south of Akrotiri (Page 1970, s. 27, fig. 16)

mentów przedmiotów metalowych, a także niewielkie kawałki malowanego tynku. $\mathrm{Na}$ podstawie tych danych wysunął on hipotezę, że założenie to stanowi pozostałość po wieży obronnej z okresu PC I. Inni badacze uważają jednak, że obecność marmuru oraz malowanego tynku wymownie wskazuje na relikty willi, zamieszkanej przez bardzo ważną osobę ${ }^{98}$.

${ }^{98}$ Doumas 1983, s. 55-56; Sperling 1973, s. 24. 
(h) Około 600 m na wschód od osiedla Akrotiri, w Potamos (Kamara), podczas PEB znajdowała się również osada, która w 1899 r. została zbadana przez R. Zahna. Odkrył on pozostałości, które określił jako pomieszczenia magazynowe lub zdaniem innych badaczy - stanowiąca części domu. Ściany tej konstrukcji zostały wzniesione z nierówno obrobionych bloków zastygłej lawy. W sąsiedztwie odkryto niewielką ścieżkę. Z inwentarza ruchomego stwierdzono między innymi fragmenty płyt kamiennych, które były prawdopodobnie elementami żarna, fragmentami prasy do wyciskania oliwy, część kolistego, złotego naszyjnika, kilka elementów sieci rybackich oraz wiele zachowanych w całości lub we fragmentach naczyń zasobowych, w tym ułamek wylewu z inskrypcją w piśmie linearnym A. Ponadto pozyskano znaczną ilość szczątków kostnych zwierząt (świni, psa, osła lub muła). Ze szczątków roślinnych trzeba wymienić nasiona jęczmienia, anyżu, dzikiego grochu i kolendry. Zdaniem C. Doumasa kompleks ten stanowił część osiedla Akrotiri. Miejsce wykopalisk R. Zahna pozostaje niestety nieznane, ze względu na brak odnośnej dokumentacji planistycznej ${ }^{99}$.

(i) Bardziej na północny wschód od Potamos (Kamara), a około 1 km od Akrotiri, na skraju kaldery, zlokalizowany jest kamieniołom Mavromatis, w którym również zarejestrowano liczne fragmenty ceramiczne. Zdaniem C. Doumasa, właśnie w tym miejscu mogło się znajdować suburbium Akrotiri ${ }^{100}$.

Z okresu PC I znane jest przynajmniej osiem osad z półwyspu Akrotiri, co dobitnie świadczy o atrakcyjności tego miejsca do celów osadniczych. Wiadomo o istnieniu jeszcze kilku osad z tego okresu również w innych częściach Thiry. Nie mają one jednak tak zwartego charakteru jak na półwyspie Akrotiri. Są to w dużej mierze wsie o rozproszonej zabudowie oraz samodzielne gospodarstwa.

(j) Taki charakter miała zapewne osada zbadana przez C. Doumasa we Ftellos, nieopodal Fira. Odsłonił on tutaj dwa pomieszczenia wraz z podwórzem oraz konstrukcję przypominającą stajnię. Jej dach wsparty był na jednej centralnej kolumnie lub słupie drewnianym (ryc. 23) ${ }^{101}$.

(k) Podczas zakładania rowów sondażowych na wzgórzu Profitis Ilias badacze francuscy H. Mamet i H. Gorceix natknęli się na mury pochodzące z okresu PC ${ }^{102}$.

(l) Na północy wyspy, niedaleko miejscowości Oia, w jednym z kamieniołomów odkryto ślady zasiedlenia tego miejsca w okresie PC I. C. Doumas zakłada, że była to największa osada spośród tych wysuniętych na północ. Mogła pełnić podobną rolę jak Akrotiri. Dodaje on także, że mogła mieć duże znaczenie w kontaktach z wyspą Ios ${ }^{103}$.

(m) Kolejnym miejscem, gdzie sytuuje się osadę z PC I, jest kamieniołom Alphouzos na Thirassii ${ }^{104}$.

\footnotetext{
${ }^{99}$ Hiller von Gaertingen 1901, s. 39-46; Doumas 1983, s. 45.

${ }^{100}$ Doumas 1983, s. 45.

${ }^{101}$ Barber 1987, s. 64-66.

${ }^{102}$ Mamet i Gorceix 1870, s. 183-203; Sperling 1973, s. 34.

${ }^{103}$ Doumas 1983, s. 129.

${ }^{104}$ Lenormant 1866, s. 423-432; F ou qué 1879, s. 94-103; Sperling 1973, s. 39, 40, 56-61.
} 


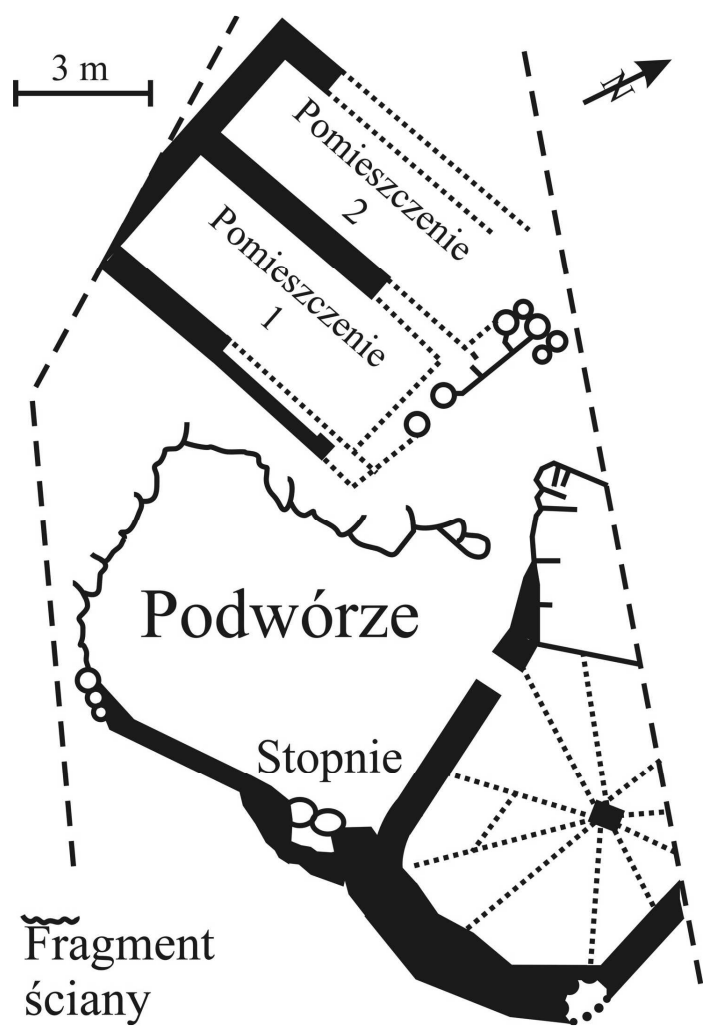

Ryc. 23. Ftellos PEB (wg Doumas 1973)

Fig. 23. Ftellos (Late Bronze Age) (Dou mas 1973)

(n) Zakłada się również istnienie pewnej osady na dzisiejszej niewielkiej wysepce Aspronisi. W okresie PC musiała odgrywać znaczną rolę, ponieważ znajdowała się przy wejściu do kaldery od strony zachodniej. Hipotezę tę można potwierdzić, opierając się na znalezionych bardzo wielu fragmentach ceramicznych datowanych na późną epokę brązu ${ }^{105}$.

(o) Osada na półwyspie Akrotiri, położona niedaleko od współczesnej latarni morskiej w jednym z wąwozów, zbadana przez S. Marinatosa. Materiał archeologiczny to głównie ceramika z okresów ŚC i PC ${ }^{106}$.

Pozostałe stanowiska, które należy jeszcze przytoczyć, to w dużej mierze jedynie ślady osadnicze, wyznaczone na podstawie niewielu fragmentów ceramicznych.

(p) Chodzi tu między innymi o okolice Exomiti, miejscowości położonej w najbardziej na południe wysuniętej części wyspy, gdzie zarejestrowano jedno naczynie, charakterystyczne dla okresu PC I.

\footnotetext{
${ }^{105}$ Forsyth 1997, s. 49.

${ }^{106}$ Marinatos 1976 , s. 12
} 
(q) Należy jeszcze wspomnieć o jednym naczyniu zasobowym z okresu PC, znalezionym niedaleko miejscowości Sellada w pobliżu masywu Mesa Vouno, które pochodziło zapewne $\mathrm{z}$ inwentarza grobowego.

(r) Kilka fragmentów ceramicznych, datowanych na interesujący nas odcinek czasu, zarejestrowano również w kontekście grobowym na półwyspie Koloumbos, w północno-wschodniej części Thiry ${ }^{107}$.

Są to prawie wszystkie znane dotychczas stanowiska na wyspie datowane na późną epokę brązu. Wolno jednak przypuszczać, że pod grubą warstwą materiału wulkanicznego znajduje się jeszcze wiele śladów osadnictwa z różnych okresów. Uważa się zatem, że Thira w późnej epoce brązu stanowiła prawdopodobnie najgęściej zasiedlony obszar ze wszystkich wysp Archipelagu Cykladzkiego. Jego eksponowaną pozycję należy przypisywać dominującej roli w dalekosiężnym handlu, wywołanej położeniem na skrzyżowaniu szlaków handlowych łączących Grecję kontynentalną i wyspę Kretę, z wybrzeżami Azji Mniejszej i innymi wyspami Morza Egejskiego ${ }^{108}$.

\subsection{Osada Akrotiri w początkowej fazie katastrofy. Preludium do „wielkiego wybuchu”}

Na początku okresu PC I/ wczesny PM IA, w południowej części Archipelagu Cykladzkiego nastapiło wielkie trzęsienie ziemi, które swoim niszczącym działaniem najbardziej dotknęło Kretę. Jednakże również na innych Wyspach Egejskich (Thira, Kos, Rodos) czytelne są ślady destrukcji ${ }^{109}$. Jedną z poszkodowanych osad było Akrotiri na Thira. Jak uważał S. N. Marinatos, nie były to zbyt silne trzęsienia ziemi, ponieważ pozwoliły mieszkańcom na opuszczenie osady wraz z cenniejszymi dla nich przedmiotami (metale i narzędzia) ${ }^{110}$. Wiele przedmiotów, których nie udało się zabrać, pozostawiono w miejscach najmniej narażonych na zniszczenia, szczególnie naczynia zasobowe z żywnością. Ponadto brak jakichkolwiek śladów ofiar tego kataklizmu potwierdza wcześniejsze bezpieczne opuszczenie osady przez mieszkańców ${ }^{111}$. Później osada ta dotknięta została przez kolejne, o wiele większe wstrząsy ${ }^{112}$. Po ich ustąpieniu pewne grupy mieszkańców (znanych w literaturze przedmiotu jako squatters) powróciły do domów, aby usnąć zniszczenia ${ }^{113}$. Ślady ich działalności są czytelne w odkrytym materiale (oczyszczenie Drogi Telchinów, zgarnięte sterty gruzów w niektórych miejscach na osadzie). Po uprzątnięciu miasta podjęli zapewne odbudowę zawalonych obiektów.

\footnotetext{
${ }^{107}$ Scholes 1956, s. 13; Barber 1981, s. 20.

${ }^{108}$ Forsyth 1997, s. 49, 50.

${ }^{109}$ Marketou 1990, s. 100-113; Marinatos 1970, s. 66.

${ }^{110}$ Marinatos 1968 , s. $55 ; 1969$, s. 5.

${ }^{111}$ Doumas 1974, s. 110, 111

${ }^{112}$ Marinatos 1970, s. 64

${ }^{113}$ Marinatos 1970, s. 64
} 
Mury silnie nadwerężone zostały zburzone (prawdopodobnie za pomocą ogromnych kamieni w kształcie młotów o wadze 13 do $15 \mathrm{~kg}$, znalezionych podczas eksploracji), a następnie wzniesione na nowo. Ściany pokryto tynkiem. Reszki tego tynku zostały zarejestrowane $\mathrm{w}$ dwóch naczyniach pozostawionych $\mathrm{w}$ jednym $\mathrm{z}$ pomieszczeń DZ. Prace budowlane zapewne trwały jeszcze, gdy wystąpiły pierwsze symptomy działalności wulkanicznej. Wówczas ostatecznie miasto opuszczono ${ }^{114}$.

BIBLIOGRAFIA

Barber R. L. N.

1981 The Late Cycladic Period: A Review, ,The Annual of the British School at Athens” 76, s. 1-21.

1987 The Cyclades in the Bronze Age, London.

Branigan $\mathrm{K}$.

1981 Minoan Colonialism, „Annual of the British School of Athens” 76, s. 23-33.

1984 Minoan Community Colonies in the Aegean? (w:) The Minoan Thalassocracy: Myth and Reality, red. R. Hägg i N. Marinatos, Stockholm, s. 49-53.

Cherry J. F.

1981 Pattern and process in the Earliest Colonization of the Mediterranean Islands, „Proceedings of the Prehistoric Society" 4, s. 41-68.

Davidson D. A.

1979 Aegean Soils During the Second Millennium B.C. (w:) Thera and the Aegean World I. Papers presented at the Second International Scientific Congress, Santorini, Greece, August 1978, C. G. Doumas, J. A. Sakellarakis, P. M. Warren, London, s. 725-739.

Davis E. N.

1990 The Cycladic Style of the Thera Frescoes, (w:) Thera and the Aegean World III: Archaeology, red. D. A. Hardy, C. G. Doumas, J. A. Sakellarakis, P. M. Warren, London, s. 214-228.

Davis J. L., Cherry J. F.

1990 Spatial and Temporal Uniformitarianism in late Cycladic I: Perspectives from Kea and Milos on the Prehistory of Akrotiri, (w:) Thera and the Aegean World III: Archaeology, red. D. A. Hardy, C. G. Doumas, J. A. Sakellarakis, P. M. Warren, London, s. 185-200.

Doumas C. G.

1974 The Minoan eruption of the Santorini volcano, „Antiquity” 48, s. 110-115, 190-200.

1983 Thera: Pompeii of the Ancient Aegean: Excavations at Akroteri, 1967-1979, London.

1990 Archaeological Observations at Akrotiri Relating to the Volcanic Destruction, (w:) Thera and the Aegean World III. Vol. 3: Chronology. Proceedings of the Third International Congress, Santorini, Greece, 3-9 September 1989, red. D. A. Hardy, C. A. Renfrew, London, s. 48-50.

Faure $P$.

1971 Remarques sur la présence et l'emploi de la Pierre Ponce en Crete du Néolithique à nos jours, (w:)

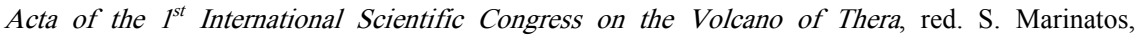
D. Ninkovich, Athens, s. 422-429.

Forsyth P. Y.

1997 Thera in the Bronze Age, New York.

Fouqué F.

1879 Santorini et ses eruptions, Paris.

${ }^{114}$ Doumas 1974 , s. $110-112$. 
Friedrich W. L.

2000 Fire in the Sea. The Santorini Volcano: Natural History and the Legend of Atlantis, Cambridge.

Friedrich W. L., Doumas C.

1990 Was there Local Access to Certain Ores/Minerals for the Theran People before the Minoan Eruption? An Addendum, (w:) Thera and the Aegean World III: Archaeology, red. D. A. Hardy, C. G. Doumas, J. A. Sakellarakis, P. M. Warren, London, s. 502-503.

Hiller von Gaertringen F. 1901 Thera III, Berlin.

Lenormant F.

1866 Découverte de constructions antéhistoriques dans l'île de Thérasia, „Revue archéologique” 14, s. $423-432$.

Lewartowski K., Ulanowska A.

1998 Archeologia egejska. Grecja od epoki paleolitu po wczesną epokę żelaza, Warszawa.

Mamet $\mathrm{H}$

1874 De Insula Thera thesim Facultati litterarum parisiensi proponit H. Mamet, Paris, s. 27-30.

Mamet H., Gorceix H.

1870 Recherches et fouilles faite à Théra, „Bulletin de l'École Française d'Athènes” 9, s. 183-203.

Marinatos S. N.

1968 Excavations at Thera, First Preliminary Report(1967 season), Athens.

1969 Excavations at Thera II(1968 season), Athens.

1970 Excavations at Thera III(1969 season), Athens.

1971a Excavations at Thera III(1970 season), Athens.

1971b Excavations at Thera IV(1970 season), Athens.

1972 Excavations at Thera V(1971 season), Athens.

1974 Excavations at Thera VI(1972 season), Athens.

1976 Excavations at Thera VII(1973 season), Athens.

Marketou T.

1990 Santorini Tephra from Rhodes and Kos: Some Chronological Remarks Based on the Stratigraphy, (w:) Thera and the Aegean World III: Chronology, red. D. A. Hardy, A. C. Renfrew, London, s. 29-40.

Marthari M.

1990 The Chronology of the Last Phases of Occupation at Akrotiri in the Light of the Evidence from the West House Pottery Groups, (w:) Thera and the Aegean World III: Chronology, red. D. A. Hardy, A. C. Renfrew, London, s. 57-70.

1997 The local pottery wares with painted decoration from the Volcanic Destruction Level of Akrotiri, Thera. A preliminary report, „Archaologischer Anzeiger” 1987, s. 359-379.

Moundrea-Agrafioti A.

1990 Akrotiri, the Chipped Stone Industry: Reduction Techniques and Tools of the LC I Phase, (w:) Thera and the Aegean World III: Archaeology, red. D. A. Hardy, C. G. Doumas, J. A. Sakellarakis, P. M. Warren, London, s. 390-406.

Page D. L.

1970 The Santorini Volcano and the Desolation of Minoan Crete, London.

Palyvou C.

1984 The destruction of the town at Akrotiri, Thera, at the beginning of LCI: rebuilding activities, (w:) The Prehistoric Cyclades, red. J. A. MacGillivray, R. L. N. Barber, Edinburgh, s. 134-147

1986 Notes on the Town Plan of Late Cycladic Akrotiri, „Bulletin of the Institute of Classical Studies of the University of London" 81, s. 179-194.

1990 Architectural Design at Late Cycladic Akrotiri, (w:) Thera and the Aegean World III, Archaeology, red. D. A. Hardy, C. G. Doumas, J. A. Sakellarakis, P. M. Warren, London, s. 44-56. 
Papagiannopoulou A. G.

1991 The Influence of Middle Minoan Pottery on the Cyclades, Göteborg.

Renfrew C. A.

1969 The Development and Chronology of the Early Cycladic Figurines, „American Journal of Archaeology" 73, s. 1-32.

1971 Obsidian and Pumice: The Use of Recent Igneous Rock in Aegean Prehistory, (w:) Acta of the $1^{\text {st }}$ International Scientific Congress on the Volcano of Thera, red. S. Marinatos, D. Ninkovich, Athens, s. $430-436$.

1972 The Emergence of Civilisation: The Cyclades and the Aegean in The Third Millennium BC, London. Sakellarakis I. A.

1977 Art and Culture of the Cyclades in the Third Millennium B. C., red. J. Thimme, Karlsruhe, s. 146.

Scholes K.

1956 The Cyclades in the Later Bronze Age: A Synopsis, „The Annual of the British School at Athens” 51, s. 13.

Sotirakopoulou P.

1990 The Earliest History of Akrotiri: The Late Neolithic and Early Bronze Age Phases, (w:) Thera and the Aegean World III: Chronology, red. D. A. Hardy, A. C. Renfrew, London, s. 41-47.

1990a Archaeological Observations at Akrotiri Relating to the Volcanic Destruction, (w:) Thera and the Aegean World: Chronology, red. A. C. Renfrew, London, s. 48-50.

Sperling J. W.

1973 Thera and Therasia, Athens.

Van Andel T.H. i C. N. Runnels

1988 An Essay on the Emergence of Civilization in the Aegean World, „Antiquity” 62, s. 234-247.

\section{BIBLIOGRAFIA GRECKA}

M $\alpha \rho \theta \alpha \dot{\rho}$ M.

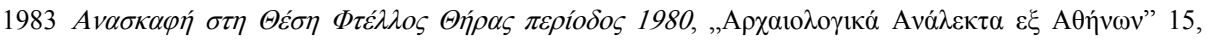
s. $86-101$.

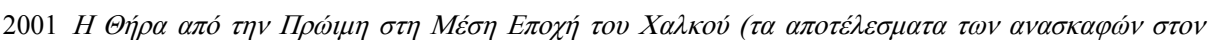

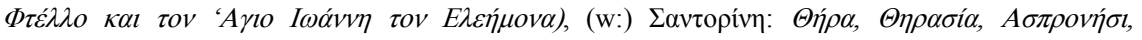

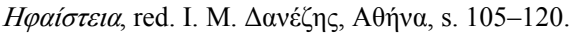

$\mathrm{N} \tau$ ov́ $\mu \alpha \varsigma \mathrm{X}$

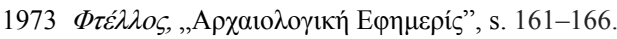

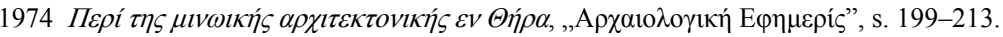

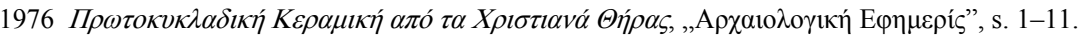

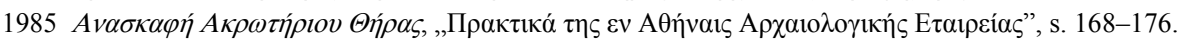

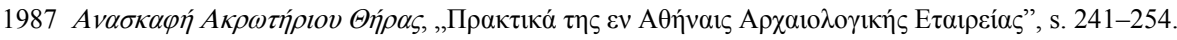

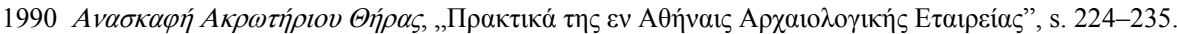

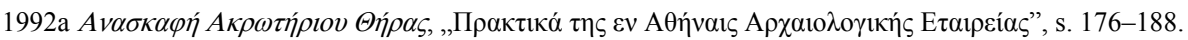

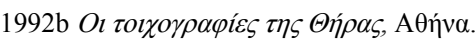

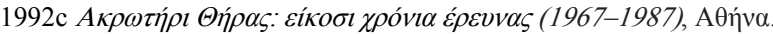

$\Pi \alpha \lambda v \beta$ ov́ $\mathrm{K}$.

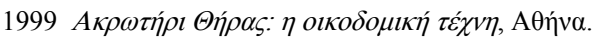


$\Sigma \omega \tau \eta \rho \alpha \kappa о \pi о v ́ \lambda$ ov П.

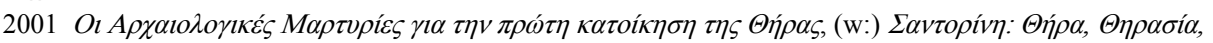

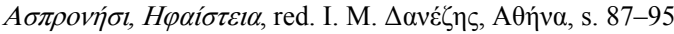

$\mathrm{T} \varepsilon \lambda \varepsilon \beta \alpha \dot{v} \tau$ ○ $\mathrm{X}$

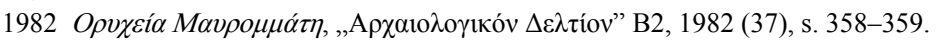

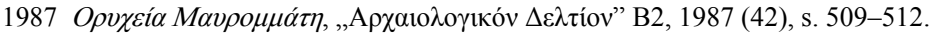

\section{THE OCCUPATION OF THERA ISLAND (SANTORINI) \\ FROM THE NEOLITHIC UNTIL THE LATE BRONZE AGE}

\section{S u m m a r y}

A history of the Neolithic and Bronze Age settlements on what is now known as the island of Santorini (Thera) has been investigated in details in the second half of the $20^{\text {th }}$ century. Unfortunately, the results of these studies were published only in the local foreign language magazines. The article aims to familiarize a Polish reader with this completely exotic theme, as seen from the viewpoint of the Polish research milieu, which however remains extremely important for the study of the periods in question in Europe. The article provides an overview of this occupation. Firstly, it discusses the Neolithic settlements followed by those dated to Early Bronze Age, itself divided into three periods: Early Cycladic I, II, III. Secondly, the island occupation of the island during the Middle and Late Cycladic periods has been brought up. The abandonment of the city of Akrotiri in the Late Cycladic phase was caused by the eruption of Thera volcano. This event marks the beginning of a long hiatus in the island occupation.

Translated by Ewa Loba-Bronowicka 